University of California, Hastings College of the Law UC Hastings Scholarship Repository

Faculty Scholarship

2015

\title{
Unavoidable Aesthetic Judgments in Copyright Law: A Community of Practice Standard
}

Ben Depoorter

UC Hastings College of the Law, depoorter@uchastings.edu

Robert Kirk Walker

Follow this and additional works at: http://repository.uchastings.edu/faculty_scholarship

\section{Recommended Citation}

Ben Depoorter and Robert Kirk Walker, Unavoidable Aesthetic Judgments in Copyright Law: A Community of Practice Standard, 109 Nw. U. L. Rev. 343 (2015).

Available at: http://repository.uchastings.edu/faculty_scholarship/1459

This Article is brought to you for free and open access by UC Hastings Scholarship Repository. It has been accepted for inclusion in Faculty Scholarship by an authorized administrator of UC Hastings Scholarship Repository. 


\section{UNAVOIDABLE AESTHETIC JUDGMENTS IN COPYRIGHT LAW: A COMMUNITY OF PRACTICE STANDARD}

ABSTRACT-Aesthetic judgments are "dangerous undertakings" for courts, but they are unavoidable in copyright law. In theory, copyright does not distinguish between works on the basis of aesthetic values or merit (or lack thereof), and courts often go to great lengths to try to avoid artistic judgments. In practice, however, implicit aesthetic criteria are deeply embedded throughout copyright case law. The questions "What is art?" and "How should it be interpreted?" are inextricably linked to the questions "What does copyright protect?," "Who is an author?," "What is misappropriation?," and many other issues essential to copyright. Although courts rarely (if ever) explicitly adhere to aesthetic principles in their decisions, the judicial logic used in copyright cases closely mirrors three major aesthetic theories: Formalism, Intentionalism, and Reader-Response. Unfortunately for courts, these theories are largely incompatible. Furthermore, none are sufficiently expansive to cover the variety of practices contained within a single artistic tradition, let alone the panoply of expressive mediums protected by copyright law. As a result, doctrinal inconsistencies abound (both inter- and intra-circuit), and the case law largely fails to provide clear guidance as to the scope of protection-and risk of liability-associated with different artistic practices. This Article examines how courts have applied aesthetic theories to resolve doctrinal issues concerning copyright eligibility, derivative works, useful articles, and statutory fair use. Based on this analysis, this Article argues that courts should adopt a uniform approach to aesthetic judgments from the perspective of a hypothetical "Community of Practice" capable of situating an expressive work in a specific artistic context.

AuThoR-Ben Depoorter is a Professor of Law \& Hastings Research Chair, University of California, Hastings College of the Law; Affiliate Scholar, Stanford Law School, Center for Internet \& Society; and Lecturer, Ghent University. Robert Kirk Walker is an Affiliate Scholar, University of California, Hastings. This Article benefited greatly from suggestions received from Andrew Gilden, Christopher Buccafusco, and participants at the Eleventh Annual Works-in-Progress Intellectual Property Colloquium at Santa Clara University School of Law. 


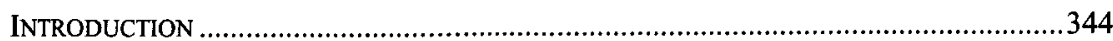

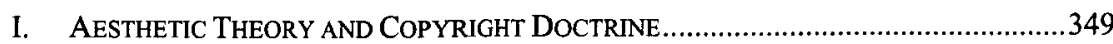

A. Bleistein and the "Doctrine of Avoidance" ...............................................350

B. Brief Survey of Aesthetic Theories Used in Copyright .................................353

II. SPECIFIC InStances of Aesthetic JUdgments in COPYRight CASE LAW............358

A. The Province of Copyright Law: Works by "Authors"..................................358

B. A "Spark of Originality" in Derivative Works.............................................362

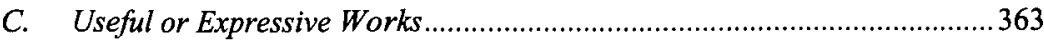

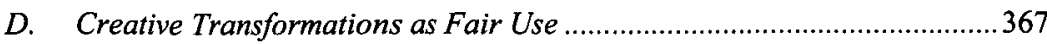

III. A “COMMUNITY OF PRACTICE" ProposAL ..........................................................371

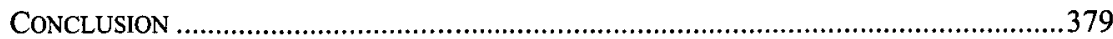

\section{INTRODUCTION}

While courts have little difficulty navigating through dense thickets of economics, ${ }^{1}$ psychology, ${ }^{2}$ science, ${ }^{3}$ and religious literature ${ }^{4}$ they become utterly flummoxed when confronted with works of art. ${ }^{5}$ This is a curious phenomenon because many judges are broadly conversant in art, ${ }^{6}$ and artistic interpretation is quite similar to the textual exegesis that is inherent to judicial practice. ${ }^{7}$ Yet, time and again, courts declare that they must

1 See, e.g., RICHARD A. POSNER, ECONOMIC ANALYSIS OF LAW (9th ed. 2014).

2 See, e.g., Bernard L. Diamond, From M'Naghten to Currens, and Beyond, 50 CALIF. L. REV. 189, 190-91, 196 (1962) (discussing the application of psychology to criminal law).

3 See, e.g., David S. Caudill \& Lewis H. LaRue, Why Judges Applying the Daubert Trilogy Need to Know About the Social, Institutional, and Rhetorical-And Not Just the Methodological-Aspects of Science, 45 B.C. L. REV. 1, 6 (2003) (discussing the law's use of scientific literature).

${ }^{4}$ See, e.g., Bruce J. Casino, Note, "I Know It When I See It": Mail-Order Ministry Tax Fraud and the Problem of a Constitutionally Acceptable Definition of Religion, 25 AM. CRIM. L. REV. 113, 130-35 (1987) (discussing the Supreme Court's attempts to define religion).

5 While many examples discussed in this Article are drawn from the cases involving visual arts (e.g., painting, sculpture, photography, etc.), the analysis presented is equally applicable to other types of creative work covered by copyright, except where otherwise noted. As such, the word "art" is used in its broadest sense.

${ }^{6}$ See, e.g., Leibovitz v. Paramount Pictures Corp., 137 F.3d 109, 111 n.I (2d Cir. 1998) (providing a 296-word footnote with a complete art-historical iconography of the "Venus Pudica" pose in a comparison of an Annie Leibovitz photograph of the actress Demi Moore and Botticelli's Birth of Venus); see also Bleistein v. Donaldson Lithographing Co., 188 U.S. 239, 249-51 (1903) (referencing artists Velasquez, Whistler, Rembrandt, Degas, Goya, and Manet, and the art critic John Ruskin)

7 Modern legal theory borrows heavily from aesthetic theory, particularly literary criticism, especially as applied to textual determinacy, the analysis of legislative intent, and the role of judges. See, e.g., Richard A. POSNER, LAW AND LiTERATURE 276-319 (3d ed. 2009); Robin West, Jurisprudence as Narrative: An Aesthetic Analysis of Modern Legal Theory, 60 N.Y.U. L. REV. 145, 203-06 (1985) (discussing aesthetic theory); James Boyd White, What Can a Lawyer Learn from Literature, 102 HARV. L. REV. 2014, 2023 (1989) (explaining the importance of literary criticism as applied to law). 
abstain from making aesthetic judgments ${ }^{8}$ on the basis that they are incompetent to do so, ${ }^{9}$ and that any artistic definition or interpretation they might offer would be subject to the whims of personal taste. Art, it seems, is like obscenity: it is something courts know when they see, but can't speak about intelligibly. ${ }^{10}$

This rather hyperbolic judicial posture ${ }^{11}$ derives from the Supreme Court's 1903 decision in Bleistein v. Donaldson Lithographing Co. ${ }^{12}$ This case has come to stand for the proposition that copyright protection is not predicated on the artistic merits of a work-i.e., copyright is not concerned with whether a work sits high or low on the brow. ${ }^{13}$ This part of the Bleistein opinion is uncontroversial. However, Justice Holmes, writing for the Court, went on to expound on the proper role of judges when faced with aesthetic controversy:

It would be a dangerous undertaking for persons trained only to the law to constitute themselves final judges of the worth of pictorial illustrations, outside of the narrowest and most obvious limits. ${ }^{14}$

In the hundred-plus years since Bleistein was decided, courts have refined Justice Holmes's admonition against the "dangerous undertaking" of artistic judgments into an interpretative principle termed the "doctrine of avoidance." 15 This doctrine holds that law and art serve discordant cultural functions: law is concerned with providing social stability, whereas art is unpredictable and challenging to social conventions. ${ }^{16}$ Furthermore, courts are not specifically "trained" in artistic assessment, and so are "illequipped" to address aesthetic questions. ${ }^{17}$ For these reasons, among

${ }^{8}$ In this Article, the terms "artistic" and "aesthetic" are used synonymously. Aesthetic theory denotes the branch of philosophy concerned with the interpretation and meaning of art. See generally AESTHETICS: A CRITICAL ANTHOLOGY (George Dickie et al. eds., 2d ed. 1989).

${ }^{9}$ See Christine Haight Farley, Judging Art, 79 TUL. L. REV. 805, 814 (2005) (“Another reason advanced for shunning artistic determinations is that the judiciary has no particular competence to assess artistic merit.").

${ }_{10}$ See Jacobellis v. Ohio, 378 U.S. 184, 197 (1964) (Stewart, J., concurring) (when faced with the task of "trying to define what may be indefinable," Justice Stewart famously declared, "I shall not today attempt further to define the kinds of material I understand to be embraced within that shorthand description [of hard-core pornography]; and perhaps I could never succeed in intelligibly doing so. But I know it when I see it ....').

${ }^{11}$ See infra Part III.

12188 U.S. 239, 251-52 (1903) (holding that commercial illustrations are "art" for the purpose of copyright protection).

${ }_{13}$ That courts do not distinguish between "high" and "low" forms of artwork in determining the scope of copyright protection is often referred to as the Bleistein nondiscrimination principle.

${ }_{14}^{14}$ Bleistein, 188 U.S. at 251.

15 See Farley, supra note 9, at 815

16 See generally ART AFTER MODERNISM: RETHINKING REPRESENTATION (Brian Wallis ed., 1984) (presenting critical essays discussing culturally provocative practices in postmodern art).

${ }^{17}$ Yurkew v. Sinclair, 495 F. Supp. 1248, 1254 (D. Minn. 1980) ("The question of what is art is inherently subjective, as 'it is nevertheless often true that one man's vulgarity is another's lyric.' It 
others, ${ }^{18}$ courts refuse to explicitly state aesthetic opinions on the basis that doing so would discriminate in favor of one interpretation of art over another, ${ }^{19}$ which could result in chilling effects on speech $^{20}$ and a covert form of censorship. ${ }^{21}$

If only courts could follow their own prescription. Despite frequent insistence to the contrary, the very types of subjective and qualitative assessments that Bleistein and its progeny sought to avoid are inextricable from copyright law. ${ }^{22}$ For instance, aesthetic judgment is required to determine whether independent contributions have "merged into inseparable ... parts of a unitary whole" for purposes of assigning joint ownership to a copyright and what (if any) part of the design of a useful article is "capable of existing independently of . . the utilitarian aspects of the article." ${ }^{23}$ In addition, to determine the scope of copyright protection, courts must apply the idea/expression dichotomy ${ }^{24}$ and the scènes à faire doctrine. ${ }^{25}$ These doctrines necessitate filtering out original expression from unprotectable ideas and stock elements. This involves an appreciation of which artistic concepts are novel and which are customary to a work's

necessarily follows that courts are ill equipped to determine such illusory and imponderable questions ...." (citation omitted)); see also Martin v. City of Indianapolis, 192 F.3d 608, 610 (7th Cir. 1999) ("We are not art critics, do not pretend to be and do not need to be to decide this case.").

18 See infra Part II.

19 See, e.g., Brandir Int'l Inc. v. Cascade Pac. Lumber Co., 834 F.2d 1142, 1145 n.3 (2d Cir. 1987); see also Amy Adler, What's Left?: Hate Speech, Pornography, and the Problem for Artistic Expression, 84 CALIF. L. REV. 1499, 1548-50 (1996) (arguing that art and law are inherently incompatible in an analysis of attempts to exempt art from the category of obscene material).

${ }^{20}$ See, e.g., Campbell v. Acuff-Rose Music, Inc., 510 U.S. 569, 582-83 (1994) (citing Bleistein and noting that whether "parody is in good taste or bad does not and should not matter to fair use"); Parks v. LaFace Records, 329 F.3d 437, 462-63 (6th Cir. 2003) (quoting Bleistein); Mattel Inc. v. Walking Mountain Prods., 353 F.3d 792, 801-02 (9th Cir. 2003) (same); SunTrust Bank v. Houghton Mifflin Co., 268 F.3d 1257, 1278 (11 th Cir. 2001) (applying Bleistein); Ets-Hokin v. Skyy Spirits, Inc. 225 F.3d 1068, 1075 (9th Cir. 2000) (citing Bleistein); Carol Barnhard Inc. v. Econ. Cover Corp., 773 F.2d 411 , 415 (2d Cir. 1985) (same).

2l See Bleistein v. Donaldson Lithographing Co., 188 U.S. 239, $251-52$ (1903) ("[C]opyright would be denied to pictures which appealed to a public less educated than the judge. Yet if they command the interest of any public ... it would be bold to say that they have not an aesthetic and educational value - and the taste of any public is not to be treated with contempt.").

${ }^{22}$ See Raymond M. Polakovic, Should the Bauhaus Be in the Copyright Doghouse? Rethinking Conceptual Separability, 64 U. CoLO. L. REv. 871, 873 (1993) (asserting that the Copyright Act requires courts to separate aesthetic and useful elements of a useful article); Alfred C. Yen, Copyright Opinions and Aesthetic Theory, 71 S. CAL. L. REV. 247, 301 (1998) ("[T]he existence of copyright makes subjective judicial pronouncements of aesthetic taste necessary."); see also infra Part III.

23 17 U.S.C. $\$ 101$ (2010); see also infra Part III.

24 See, e.g., Harper \& Row, Publishers, Inc. v. Nation Enters., 471 U.S. 539, 556 (1985) (stating that the Copyright Act permits "free communication of facts while still protecting an author's expression"); Mazer v. Stein, 347 U.S. 201, 217 (1954) ("[P]rotection is given only to the expression of the idea-not the idea itself."); see also infra Part III.

25 See, e.g., Ets-Hokin, 225 F.3d at 1082; Walker v. Time Life Films, 784 F.2d 44, 50 (2d Cir. 1986); see also infra Part III. 
genre. Similarly, whether two works are found to be "substantially similar" depends, in large part, on the level of aesthetic specificity the court chooses to apply to the work. ${ }^{26}$ Artistic intent is also frequently considered in determining whether a use of copyright material is sufficiently "transformative" to satisfy the "purpose and character" prong of the statutory fair use test. ${ }^{27}$ Moreover, in some instances a judicial determination of artistic merit and ontology is explicitly mandated by statute..$^{28}$

In sum, when faced with questions that require qualitative evaluation of works of art, judges are forced to perform analytical jujitsu: first blocking with citation to Bleistein, then attacking with an ad hoc aesthetic theory of the court's own devising. ${ }^{29}$

In performing this maneuver, some courts have focused solely on comparing the configuration of elements in a work that provokes an aesthetic reaction. ${ }^{30}$ This approach, known as Formalism, ${ }^{31}$ regards other interpretative devices, such as accuracy in representation, expressiveness, an artist's professed intent, etc., as irrelevant. Formalism is perhaps best epitomized in copyright law by Judge Learned Hand's "comparative method" of assessing musical works. ${ }^{32}$ In contrast, other courts have opted

${ }^{26}$ Compare Nichols v. Universal Pictures Corp., 45 F.2d 119, 120-21 (2d Cir. 1930) (conducting a detailed comparison of the plot and characters of two works), with Sid \& Marty Krofft Television Prods., Inc. v. McDonald's Corp., 562 F.2d 1157, 1167, 1175 (9th Cir. 1977) (finding infringement on the basis of general similarities between works). For an excellent discussion of issues of artistic interpretation in the context of copyright infringement and the test of substantial similarity, see Yen, supra note 22, at 288-97 (analyzing the interpretation of art by courts in the context of the ordinary observer test).

27 See 17 U.S.C. § 107(1) (1992); see also infra Part III. Compare Rogers v. Koons, 960 F.2d 301, 309-10 (2d Cir. 1992) (finding that the unauthorized use of a photograph in the creation of a sculpture was not parodic fair use), with Blanch v. Koons, 467 F.3d 244, 253 (2d Cir. 2006) (finding defendant's work sufficiently transformative to justify fair use defense). See generally Pierre N. Leval, Toward a Fair Use Standard, 103 HARV. L. REV. 1105 (1990).

${ }^{28}$ See, e.g., Visual Artists Rights Act, 17 U.S.C. $§ 106$ A (1990) (providing authors a right of integrity that enables them to prevent the destruction of works of "recognized stature"); Brancusi v. United States, T.D. 43063, 54 Treas. Dec. Int. Rev. 428, 428-29 (1928) (determining whether Constantin Brancusi's abstract sculpture Bird in Flight was a work of art or a mere "manufacture of metal" for purpose of determining whether a customs duty was owed); Rev. Rul. 68-232, 1968-1 C.B. 79 (prohibiting depreciation deductions from federal income tax because art is not expected to depreciate in value or become obsolete over time)

29 See, e.g., Polakovic, supra note 22, at 873.

30 See Yen, supra note 22, at 253 ("The key to defining art is the identification of the peculiar qualities that enable certain objects, [but] not others, to provoke this 'aesthetic emotion."'). For a review of some case law examples, see infra Part III.

31 See, e.g., CLIVE BELL, ART 17-18 (1958) (defining a formalist approach to art criticism).

32 Hand's method involved a note-by-note comparison of the melodies of the musical works at issue, pinpointing where identical pitches occurred at the same point in the two songs. For examples of variations on this comparative method, see Arnstein v. Porter, 154 F.2d 464, 469 (2d Cir. 1946); Haas v. Leo Feist, Inc., 234 F. 105, 107 (S.D.N.Y. 1916); and Hein v. Harris, 175 F. 875, 876-77 (S.D.N.Y. 1910). 
for a diametrically opposed approach to aesthetic questions that foregoes formal comparisons and instead focuses on the author's intention at the time she created the work. ${ }^{33}$ This aesthetic theory is commonly known as Intentionalism. ${ }^{34}$ Still other courts have looked for aesthetic guidance based on how a work is understood by "ideal readers" or an "intended audience." ${ }^{35}$ This approach is known as Reader-Response theory. ${ }^{36}$ And, as often as not, courts end up doing theoretical mix and match, ${ }^{37}$ "swapping one set of aesthetic premises for others in response to the facts of particular cases." 38

Unfortunately, these three major aesthetic theories ${ }^{39}$ are largely incompatible, ${ }^{40}$ and none are sufficiently expansive to cover the variety of practices contained within a single artistic tradition, let alone the panoply

33 See, e.g., Kieselstein-Cord v. Accessories by Pearl, Inc., 632 F.2d 989, 993-94 (2d Cir. 1980) (basing its finding of conceptual separability on evidence of plaintiff's mental processes and the reactions of others).

${ }^{34}$ See, e.g., Monroe C. Beardsley, An Aesthetic Definition of Art, in WHAT IS ART? 15, 21 (1983) (" $[A] n$ artwork is something produced with the intention of giving it the capacity to satisfy the aesthetic interest."); see also Yen, supra note 22, at 263-64; infra Part III.

${ }^{35}$ See William E. Tolhurst, On What a Text Is and How It Means, 19 BRIT. J. AESTHETICs 3, 11-13 (1979); infra Part III.

${ }^{36}$ Reader-Response theory was developed as a mode of literary criticism. See, e.g., GEORGE DICKIE, ART AND THE AESTHETIC: AN INSTITUTIONAL ANALYSIS 35-37 (1974) (arguing that an object becomes art when it is presented to members of the art world for aesthetic consideration); LOIS TYSON, CRITICAL THEORY TODAY: A USER-FRIENDLY GUIDE 154 (2014) (“[R]eader-response theorists share two beliefs: (1) that the role of the reader cannot be omitted from our understanding of literature and (2) that readers do not passively consume the meaning presented to them by an objective literary text; rather they actively make the meaning they find in literature."); see also Farley, supra note 9, at 844 (citing DICKIE, supra). For example, a Reader-Response critique of a putative artwork would assess whether or not members of the "art world" perceive and value the work as art. See Arthur Danto, The Artworld, 61 J. PHIL. 571, 581 (1964) (discussing "ready-mades" and the work of Andy Warhol).

37 Compare Kieselstein-Cord, 632 F.2d at 990 (holding based on Intentionalism and Institutionalism), with Carol Barnhart, Inc. v. Econ. Cover Corp., 773 F.2d 411, 419 (2d Cir. 1985) (analysis based on Formalism).

38 Yen, supra note 22, at 298.

39 The philosophical tradition of aesthetics dates back at least to Greek antiquity. See, e.g., ARISTOTle, POetics (Joe Sachs trans., 2006); David Sider, Plato's Early Aesthetics: The Hippas Major, 35 J. AESTHETICS \& ART CRITICISM 465 (1977). A full survey of the subject is well beyond the scope of this Article. For a general survey, see MARCIA MUELDER EATON, BASIC ISSUES IN AESTHETICS (Waveland Press 1999) (1987).

${ }^{40}$ As Part III, infra, illustrates, courts combine the three aesthetic theories in their assessment of legal issue. In addition to leading to inconsistent outcomes in the case law, it should be noted that these different approaches are incompatible from the standpoint of aesthetic theory: Formalism explicitly rejects the author's intent as irrelevant to a work (i.e., the "intentional fallacy"), and Intentionalism concerns itself with formal properties or the work to see if the artist achieved their intended goal (i.e., "She said she was doing X, but the song actually conveys Y."). Reader-Response theory is more flexible insofar as it can go either way, so in that sense it is not entirely incompatible with either Formalism or Intentionalism except that it supplants the authority of both theories as the theory of art (i.e., the audience can respond however it wants, and there is not one single "correct" reading of the work). 
of mediums protected by copyright law. As a result, doctrinal inconsistencies abound (both inter- and intra-circuit), ${ }^{41}$ and the case law largely fails to provide clear guidance as to the scope of protection-and risk of liability-associated with different ways of making art.

Therefore, to alleviate this confusion, courts need to jettison the doctrine of avoidance ${ }^{42}$ and explicitly acknowledge the necessity of aesthetic interpretation in copyright adjudication. ${ }^{43}$ This Article argues that courts should instead adopt a framework for making aesthetic determinations based upon a "Community of Practice" standard, roughly analogous to the "person having ordinary skill in the art" standard utilized in patent law. ${ }^{44}$ The proposed standard would help resolve the confusion that so often arises when art is hauled into a courtroom. First, our proposal will help allay courts' fears concerning aesthetic determinations by providing a methodology for systematically sifting through art's historical and theoretical literature and obtaining input from experts. Second, our Community of Practice standard will enable litigants to settle many aesthetic questions ex ante, which would facilitate bargaining and extrajudicial dispute resolution. Third, our proposal will promote artistic innovation by establishing clearer guidelines for artists, promoting artistic production, and potentially reducing incidents of copyright infringement. ${ }^{45}$

Part I of this Article details the various aesthetic theories that courts have used to make judgments, and analyzes the relative merits of each aesthetic approach. Part II discusses specific instances in which aesthetic judgments are required by copyright doctrine. Finally, Part III describes the proposed Community of Practice standard in detail and posits its superiority to any single aesthetic theory described in Part I.

\section{AESTHETIC THEORY AND COPYRIGHT DOCTRINE}

Aesthetic theory is the branch of philosophy concerned with the interpretation and meaning of art. ${ }^{46}$ At its core, aesthetics posits two basic questions: "What is art?" and "How should it be interpreted?" The former question, though important to a wide range of statutory provisions and

41 See Yen, supra note 22, at 274-84 (discussing the oscillation aesthetic theories used by the Second Circuit in determining cases involving useful articles).

${ }^{42}$ See Farley, supra note 9, at 815.

43 This Article is concerned primarily with the role of aesthetic interpretation in copyright law. For a discussion of the legal significance of designating a work as "art" in other fields of law, see id. at 819-37.

44 See infra Part III; see also 35 U.S.C. §103(A) (2012).

45 See infra Part IV.

46 See generally AESTHETICS: A CRITICAL ANTHOLOGY (George Dickie et al. eds., 2d ed. 1989); ARGUING ABOUT ART (Alex Neill \& Aaron Ridley eds., 3d ed. 2008). The term "aesthetics" is also used to denote theories of the beautiful, which are beyond the scope of the use of the term here. See, e.g., ARThur C. DANTo, The ABUSE Of BeAUTY: Aesthetics AND the CONCEPT OF ART 1 (2003). 
common law principles, ${ }^{47}$ has little bearing on copyright law generally. ${ }^{48}$ However, the question of how art should be interpreted is very important to copyright jurisprudence, as discussed in Part III. ${ }^{49}$ In this Part, we will assess three major theories of artistic interpretation-Formalism, Intentionalism, and Reader-Response ${ }^{50}$ - that have been used extensively, albeit covertly, by courts. ${ }^{51}$

\section{A. Bleistein and the "Doctrine of Avoidance"}

In Bleistein v. Donaldson Lithographing Co., the Court determined whether chromolithographs - an early form of color photographs ${ }^{52}$ - that had been created for use as commercial advertisements were protected as "pictorial illustrations" under copyright law. ${ }^{53}$ The respondents contended that works only qualified as "pictorial illustrations" if they were "connected with the fine arts." 54 The Court squarely rejected this argument, holding that the chromolithographs in question were pictorial illustrations protected by copyright. ${ }^{55}$ But then Justice Holmes, writing for the Court, went on to say:

It would be a dangerous undertaking for persons trained only to the law to constitute themselves final judges of the worth of pictorial illustrations, outside of the narrowest and most obvious limits. At the one extreme, some works of genius would be sure to miss appreciation. Their very novelty would make them repulsive until the public had learned the new language in which their author spoke.... At the other end, copyright would be denied to pictures which appealed to a public less educated than the judge. Yet if they command the interest of any public, they have a commercial value-it would be bold to

\footnotetext{
47 See, e.g., NEA v. Finley, 524 U.S. 569 (1998) (upholding a statutory requirement that funding from the National Endowment for the Arts must take into "consideration general standards of decency and respect for the diverse beliefs and values of the American public" when determining artistic merit and excellence for the purposes of grant-making); see also supra note 28.

${ }^{48}$ This is true with the notable exception of the Visual Artists Rights Act, which provides additional moral rights to works of art of "recognized stature." See 17 U.S.C. § 106A (2012).

49 See infra Part III.

${ }^{50}$ Reader-Response is also known in the visual arts context as Institutionalism (with some variations). See DICKIE, supra note 36 , at 35-37.

51 See Yen, supra note 22, at 252-66 (discussing major theories in aesthetics that have been utilized by courts).

${ }^{52}$ See Planographic Printing, N.Y. PUB. LIBRARY (2001), http://seeing.nypl.org/planographic.html [http://perma.cc/8PTF-7XHK].

${ }_{53} 188$ U.S. 239, 248, 251 (1903) (holding that commercial illustrations were "art" for the purpose of copyright protection); see also Diane Leenheer Zimmerman, The Story of Bleistein v. Donaldson Lithographing Company: Originality as a Vehicle for Copyright Inclusivity, in INTELLECTUAL PROPERTY STORIES 77, 77-108 (Jane C. Ginsburg \& Rochelle Cooper Dreyfuss eds., 2006). 54 Bleistein, 188 U.S. at 250 (citing Act of June 18, 1874, ch. 301, § 3, 18 Stat. 78, 79).
Id.
} 
say that they have not an aesthetic and educational value-and the taste of any public is not to be treated with contempt. ${ }^{56}$

On first impression, this passage seems commonsensical: it is not the business of courts to instruct people what art to appreciate. True enough, perhaps, but then courts are rarely (if ever) asked to settle disputes over aesthetic preferences-i.e., to be "final judges of the worth" of a putative artwork. ${ }^{57}$ Rather, the question that courts face is more fundamental: is the work in dispute art or something else $?^{58}$ And if it is art, how should it be interpreted and compared to other artworks? ${ }^{59}$ On these issues, Bleistein's prescription is less cogent.

First, the "dangerous undertaking" that Holmes warned of occurs because "persons trained only to the law" seek to make final judgments on the worth of artwork. ${ }^{60}$ By negative implication, this would suggest that judges trained in art history or aesthetics might be qualified to make such judgments. ${ }^{61}$ And even if a judge is completely ignorant of art, it might still be permissible for her to make aesthetic judgments if they are within the "narrowest and most obvious limits." What these limits are, Justice Holmes did not say, nor has any subsequent court.

Second, Holmes argued that judges should avoid aesthetic pronouncements because the potential for "commercial," "aesthetic," and "educational" values implicit in a work might escape the court's attention. ${ }^{63}$ "[I]f they command the interest of any public, they have a commercial value-it would be bold to say that they have not an aesthetic and educational value - and the taste of any public is not to be treated with contempt." J64 Justice Holmes's concern for the aesthetic preferences of persons "less educated than the judge" is admirable. ${ }^{65}$ However, the link between aesthetic, educational, and commercial value is tenuous. Even if the Bleistein Court had accepted the respondent's argument that only works "connected with the fine arts" qualified for copyright protection, ${ }^{66}$ it doesn't

56 Id. at $251-52$.

57 Id.

58 See supra note 28

59 See supra note 28 ; see also supra note 49 and accompanying text.

${ }^{60}$ Bleistein, 188 U.S. at 251-52.

61 Justice Holmes himself was qualified to make such judgments, evident from references in the Bleistein decision to Velázquez, Whistler, Rembrandt, Müller, Degas, Manet, and Goya, as well as the art historian John Ruskin. See id. at 249-52; see also OLIVER WENDELL HOLMES, Notes on Albrecht Dürer, in 1 THE COLLECTED WORKS OF JUSTICE HOLMES 153 (Sheldon M. Novick ed., 1995) (presenting an essay about artist Albrecht Dürer written by Justice Holmes). Other judges have proven themselves similarly competent to discuss art and art history. See supra note 6.

${ }^{62}$ Bleistein, 188 U.S. at 251-52.

63 Id. at 252.

${ }^{64} \mathrm{Id}$.

${ }^{65} \mathrm{Id}$.

${ }^{66} I d$. at 250 (citing Act of June 18, 1874, ch. 301, § 3, 18 Stat. 78, 79). 
necessarily follow that these works also have commercial, educational, or aesthetic value. A visit to the dumpster behind an art school would provide ample evidence of putatively worthless "fine art."

Finally, and most problematically, the types of aesthetic judgment that Justice Holmes cautioned against were simply not at issue in Bleistein. The Court had not been asked to define "fine arts" or even to construe the meaning of "connected with the fine arts." ${ }^{\text {"67 }}$ Rather, the Court was tasked with determining whether advertisements are "pictorial illustrations" within the meaning of the copyright statute. ${ }^{68} \mathrm{On}$ this question, Holmes maintained that aesthetic merits do not matter:

[T] he act however construed, does not mean that ordinary posters are not good enough to be considered within its scope. The antithesis to "illustrations or works connected with the fine arts" is not works of little merit or of humble degree, or illustrations addressed to the less educated classes; it is "prints or labels designed to be used for any other articles of manufacture."

As such, Bleistein's warnings against aesthetic judgments should properly be read as dicta; Bleistein does not explicitly hold that courts must abstain from aesthetic judgments in all instances. ${ }^{70}$ Nonetheless, subsequent courts have cited Bleistein as requiring such abstention. ${ }^{71}$

As scholars have noted, courts provide numerous reasons for avoiding aesthetic determinations under the so-called doctrine of avoidance. ${ }^{72}$ Courts have argued that aesthetics are inherently subjective and dependent on taste, which is outside the realm of what courts may properly decide. ${ }^{73}$ Similarly, the principle of judicial neutrality has been evoked to forbid aesthetic decisionmaking, ${ }^{74}$ which would elevate particular aesthetic preferences and theories over other equally valid ideas. ${ }^{75}$ Other courts have

${ }^{67}$ Id.

$68 \mathrm{Id}$.

69 Id. at 251 .

${ }^{70}$ For example, Bleistein itself contemplates that judges will make aesthetic determinations within the "narrowest and most obvious limits." Id. at 251; see Farley, supra note 9, at 818.

71 See Farley, supra note 9, at 816 n.36. For a partial list of cases citing Bleistein, see supra note 20.

${ }^{72}$ See Farley, supra note 9, at 813-19 (coining the phrase "doctrine of avoidance" and enumerating some of the reasons why courts avoid aesthetic determinations).

73 See, e.g., Smith v. Goguen, 415 U.S. 566, 573 (1974) ("[W] be a work of art to another."); see also Farley, supra note 9, at $812 \mathrm{n} .15$ (providing a list of case citations discussing subjectivity and art).

74 See Farley, supra note 9, at $811 \&$ n. 14 (listing courts and commentators who have argued that law and aesthetics should not be intermingled).

75 See id. at 813 (citing Brandir Int'l, Inc. v. Cascade Pac. Lumber Co., 834 F.2d 1142, 1145 n.3 (2d Cir. 1987)). 
pled incompetence in artistic assessment ${ }^{76}$ or have expressed concern that revealing their views on art would result in being labeled philistines, or worse. ${ }^{77}$

Courts have pursued various strategies to implement the doctrine of avoidance, ${ }^{78}$ such as substituting other issues in place of the aesthetic question,,${ }^{79}$ focusing on the weight of evidence rather than its meaning, ${ }^{80}$ or simply concluding without supporting analysis ${ }^{81}$ However, none of these avoidance techniques eliminate aesthetic questions from the judicial inquiry: they merely shift such questions to the side, out of focus. This results in an incomplete snapshot of the law, leaving out the numerous areas of copyright law that explicitly require artistic judgment. ${ }^{82}$ In these areas, a different mode of reasoning cannot substitute for actual artistic interpretation. ${ }^{83}$ As a result, the doctrine of avoidance-intended to promote objectivity and eliminate questions of taste-ironically creates a dynamic where courts must rely solely on their own subjective intuitions and apply them in an ad hoc fashion.

\section{B. Brief Survey of Aesthetic Theories Used in Copyright}

Sometimes covertly, often unconsciously, courts have drawn on artistic theory and practice for resolution of aesthetic questions. This Section offers a brief summary of some of three major theories of aesthetic interpretation often used by courts. ${ }^{84}$

${ }^{76}$ See, e.g., Bucklew v. Hawkins, Ash, Baptie \& Co., 329 F.3d 923, 929 (7th Cir. 2003); Martin v. City of Indianapolis, 192 F.3d 608, 610 (7th Cir. 1999); Yurkew v. Sinclair, 495 F. Supp. 1248, 1254 (D. Minn. 1980); see also Farley, supra note 9, at 814.

${ }^{77}$ See Farley, supra note 9, at 815 ("[E]ven culturally elite judges fear the exposure that can be caused by laying bare their views on art." (citing Gracen v. Bradford Exch., 698 F.2d 300, 304 (7th Cir. 1983))); $c f$. Hilton Kramer, The ReVenge OF THE Philistines: ART AND CUlture, 1972-1984, at 382-83 (1985) ("[W]hereas Pop art had shocked its initial public with a show of campy humor and facetious charm[,] . . . the new expressionism looked to be in dead earnest.")

${ }^{78}$ See Farley, supra note 9, at 836-39 (discussing different analytical maneuvers used by courts to avoid aesthetic questions).

79 See, e.g., Rogers v. Koons, 960 F.2d 301, 310 (2d Cir. 1992) (exhibiting how the circuit court avoided the pertinent question of whether appropriation art constitutes fair use by focusing instead on legal requirements for parody).

${ }^{80}$ See, e.g., Martin, 192 F.3d at 612-14 (concluding that a sculpture was of "recognized stature" based upon volume of documents regarding the work, rather than what the documents said about the sculpture's artistic status).

${ }^{81}$ See, e.g., Gracen, 698 F.2d at 305 ("True, the background in Miss Gracen's painting differs from that in Figure 2, but it is drawn from the movie set. We do not consider a picture created by superimposing one copyrighted photographic image on another to be 'original' ....").

82 See infra Part III.

83 See Yen, supra note 22, at 301; Polakovic, supra note 22, at 873; see also infra Part III (discussing specific areas where aesthetic judgment is required in copyright law).

${ }^{84}$ As Professor Alfred C. Yen has observed, the "analytical premises of copyright opinions are practically identical to those of major aesthetic theories." Yen, supra note 22, at 250. 
1. Objective Meanings of a Work: Formalism.-Formalist theory defines art based on the "peculiar qualities that enable certain objects, [but] not others, to provoke ... aesthetic emotion." ${ }^{85}$ Following this theory, a good artwork arouses an emotional experience in a sensitive observer through the interrelationship of its formal qualities-line, shape, color, etc. ${ }^{86}$ For a Formalist, aesthetic sensation is derived solely from a work's configuration ${ }^{87}$ Neither the artist's state of mind at the work's creation, nor the subject matter contained in the work, is relevant to its status as art. ${ }^{88}$ Knowledge of the artist's ideas or biography may even be detrimental to a proper understanding of an artwork because these details might distract a viewer from fully appreciating a work's form. ${ }^{89}$

If the meaning of a work is intrinsic to the work itself, then a viewer can discern this meaning through empirical inquiry without recourse to personal views..$^{90}$ Thus, a single, objective, "correct" interpretation of the work is theoretically possible. ${ }^{91}$ Moreover, because the focus in Formalist interpretation is solely based on the qualities of a work that are aesthetically moving (e.g., shapes that are pleasing, sounds that are harmonious), and knowledge of the artist's life or work is not required, ${ }^{92}$ some theorists have maintained that a lay observer is capable of making aesthetic judgments equal to those of an expert. In this way, Formalism seems to provide an elegant solution to the problem of subjectivity and taste: art is not just in the eye of the beholder. For this reason, among others, ${ }^{93}$ Formalism is a favorite go-to position for courts. ${ }^{94}$

85 Yen, supra note 22, at 253; see also BELL, supra note 31 , at 17; HAROLD ROSENBERG, THE DEDEFINITION OF ART 11 (1972).

${ }^{86}$ Farley, supra note 9, at 842; see also JOHN ANDREW FISHER, REFLECTING ON ART 250-55, 262 (1993)

${ }^{87}$ See, e.g., BELL, supra note 31, at 27-28 (“[T] 0 appreciate a work of art we need bring with us nothing from life, no knowledge of its ideas and affairs, no familiarity with its emotions. Art transports us from the world of man's activity to a world of aesthetic exultation."); see also Yen, supra note 22, at $261-62$.

88 See, e.g., BELL, supra note 31, at 19 ("In pure aesthetics we have only to consider our emotion and its object: for the purposes of aesthetics we have no right, neither is there any necessity, to pry behind the object into the state of mind of him who made it.").

${ }^{89}$ See W.K. Wimsatt \& M.C. Beardsley, The Intentional Fallacy, 54 SEWANEE REV. 468, 487 (1946) ("Critical inquiries are not settled by consulting the oracle.").

90 See, e.g., BELL, supra note 31, at 27-28 ("For a moment we are shut off from human interests; our anticipations and memories are arrested; we are lifted above the stream of life.... In this world the emotions of life find no place. It is a world with emotions of its own.").

91 See Wimsatt \& Beardsley, supra note 89 , at 469 ("A poem can be only through its meaningssince its medium is words-yet it is, simply is, in the sense that we have no excuse of inquiring what part is intended or meant.").

92 See BELL, supra note 31, at 19.

93 For example, Formalism is considered more commonsensical and instinctual than other aesthetic theories. See Yen, supra note 22, at 262 ("[F]ormalist theories of interpretation bear a rough resemblance to the interpretive approach that many laypersons might take."). 
However, Formalism has serious interpretative weaknesses and blind spots. For example, consider the following sentence: "Half the people you know are below average." Should this be interpreted as a statement of fact, or a humorous quip? Does it help to know that the phrase is popularly attributed to comedian Steven Wright? ${ }^{95}$ The true meaning of the statement cannot be derived through the Formalist method because the source of the statement is not contained in the text. A reader-listener would have to know the sentence was written by a comedian in order to grasp its full meaning. ${ }^{96}$ Similarly, Formalism utterly fails to account for many movements in modem and contemporary art that emphasize the conceptual and referential content of a work over its physical qualities. ${ }^{97}$

2. The Author's State of Mind: Intentionalism.-Whereas Formalism regards authorial intent as irrelevant to a work's meaning, ${ }^{98}$ Intentionalism holds that artists' creative motivations are paramount to understanding their art.9 According to this theory, "[A]n artwork is something produced with the intention of giving it the capacity to satisfy the aesthetic interest." 100 Under this definition, for a work to be considered art it must have arisen from an artist's volition: accidental acts of beauty are not art. ${ }^{101}$ As such, an objective interpretation of a work of art can only be derived from inquiry into the state of mind of the artist at the moment of creation. ${ }^{102}$ For example, an Intentionalist reading of "half the people you know are below average," could identify that the sentence was meant as a joke, on the basis that the writer was a comedian and the sentence was uttered as part of a stand-up routine.

94 See, e.g., Arnstein v. Porter, 154 F.2d 464, 473 (2d Cir. 1946) (applying a formalist approach to compare two songs); see also infra Part III.

95 See The Mind of Steven Wright..., ENGL. TCHRS. NETWORK ISRAEL (1997), http://www. etni.org.il/farside/mindgames.htm [http://perma.cc/6LT3-JTL4].

96 See, e.g., Tolhurst, supra note 35, at 3-14 (discussing a similar example: "Nixon is the best president since Lincoln"); see also Yen supra note 22, at 262.

97 For example, Dada, Minimalism, Process Art, Performance Art, Conceptual Art, and Appropriation Art all deemphasize the making of aesthetically pleasing objects in favor of presenting "art as an idea." See generally JONATHAN FInEBERG, ART SinCE 1940: Strategies OF BeING 14-17 (1995); LuCy LipPard, SIX Years: The Dematerialization OF THE ART OBJECt (1973); IRving SANDLER, ART OF THE POSTMODERN ERA: From THE LATE 1960S TO THE EARLY 1990S, at 332-74 (1996).

98 See, e.g., supra notes 30-32 and accompanying text.

99 See, e.g., Beardsley, supra note 34, at 21; see also Farley, supra note 9, at 843 (explaining that Intentionalism calls for observers to have "some insights into the creative mind of the artist" to properly evaluate the object itself).

100 Beardsley, supra note 34 , at 21

101 Id. at 28.

102 See generally E. D. HIRSCH, JR., THE AIMS OF INTERPRETATION (1976) (defending Intentionalism). 
However, as one leading Intentionalist readily concedes: "[I]ntentions, being private, are difficult to know." 103 Evidence of an artist's intentions is frequently missing or uncertain (as is often the case when the artist is deceased) ${ }^{104}$ or an artist may simply be inarticulate. ${ }^{105}$ More worrisome still, even unambiguous statements of intent may be self-serving and erroneous. ${ }^{106}$ For example, an author may claim to have had a conscious intention that was not actually present at the time of creation. ${ }^{107}$ Such uncertainty presents particular risks in litigation, where artists have a strong motivation to represent their intentions in the light most favorable to their legal position.

3. The Audience's Mind: Reader-Response Theory.--In response to the interpretative weaknesses of both Formalism and Intentionalism, some aesthetic theorists have posited that the meaning of a work of art is only what exists in the minds of its audience, a theory known as ReaderResponse. ${ }^{108}$ The most extreme version of this theory holds that works of art never have a fixed or universally accepted meaning. ${ }^{109}$ Because no two readers share the same set of aesthetic assumptions, there can be no

103 Beardsley, supra note 34, at 23.

104 The process of identifying an artist's intent through extrinsic evidence is roughly analogous to the determination of a perpetrator's mens rea at the time of their crime.

${ }_{105}$ For example, Abstract Expressionist painter Jackson Pollock was famous for his inability to talk about his own work. See, e.g., Maria Popova, Jackson. Pollock on Art, Labels, and Morality, Shortly Before His Death, BRAIN PICKINGS, http://www.brainpickings.org/index.php/2013/04/09/jacksonpollock-selden-rodman-conversations-with-artists/ [http://perma.cc/C2MH-2SX5] ("[Pollock] talks with difficulty, searching painfully, almost agonizingly, for the right word, with constant apologies 'for not being verbal."' (quoting SELDON RODMAN, CONVERSATIONS WITH ARTISTS 81 (1957))).

106 See, e.g., JOSEPH WOOD KRUTCH, EDGAR ALLEN POE: A STUDY IN GENIUS 98 (1926) (disputing the methods Poe claimed to have used in writing The Philosophy of Composition, calling them instead: "[A] highly ingenious exercise in the art of rationalization [rather] than literary criticism ...."); see also Yen, supra note 22, at 263-64 ("[E]vidence of an author's intention is often missing or unclear.").

107 Take, for example, Krzysztof Penderecki's musical composition Threnody for the Victims of Hiroshima. This piece was originally titled $8^{\prime} 37$ (likely an homage to John Cage's musical composition titled $4^{\prime} 33^{\prime \prime}$ ), but it was retitled to reference the destruction of Hiroshima after listeners noted similarities to the sound of bombs dropping and people screaming. See Threnody to the Victims of Hiroshima - Krzysztof Penderecki, CulTURE.PL (Apr. 30, 2014), http://culture.pl/en/work/threnody-tothe-victims-of-hiroshima-krzysztof-penderecki [http://perma.cc/VS5-PQKA?type-live]. Therefore, whatever associations the listeners might draw between the piece and the bombing of Hiroshima cannot be credited to the composer's intentions.

108 See, e.g., Peter Jaszi, Who Cares Who Wrote "Shakespeare"?, 37 AM. U. L. REV. 617, 619-20 (1988) (" $[T]$ he object of critical attention is the structure of the reader's experience, not any 'objective' structure to be found in the work itself." (quoting TERRY EAGLETON, LITERARY THEORY: AN INTRODUCTION 85 (1983))). See generally Jane P. Tompkins, An Introduction to Reader-Response Criticism, in READER-RESPONSE CRITICISM: FROM FORMALISM TO POST-STRUCTURALISM, at ix (Jane P. Tompkins, ed., 1980).

109 See Tompkins, supra note 108, at xix-xx (discussing the theories of Norman Holland, wherein "interpretation is a function of identity," and David Bleich, wherein "meaning depends entirely on the process of symbolization that takes place in the mind of the reader"). 
consensus as to the "correct" meaning of a work, and interpretation is a mere function of the reader's preferences. ${ }^{10}$ Thus, all aesthetic disagreements are unresolvable matters of personal taste. ${ }^{11}$

Other Reader-Response theorists, however, contend that such relativism can be avoided if one presupposes that some readers are more accurate than others. For instance, an Elizabethan scholar's interpretation of the text of Julius Caesar is likely to be more accurate than a seventhgrader's. From this, one can imagine a hypothetical "ideal reader" or "intended audience" capable of supplying the most plausible (if never precisely correct) interpretation of a work. ${ }^{112}$

Unfortunately, in practice, Reader-Response theory can often morph into an ersatz form of either Formalism ${ }^{113}$ or Intentionalism. ${ }^{114}$ For example, if the best interpretation of a work is derived from its reception by the author's "intended audience," then this hypothetical audience is likely to hold values and beliefs that are very close (if not identical) to the persons that the author intended to communicate with in the first place. ${ }^{1{ }^{15}}$ Thus, the artist's intentions largely control the composition of the "intended audience," causing analysis of the audience's response to yield a result similar to Intentionalism. ${ }^{116}$ Furthermore, Reader-Response theory holds within it the potential danger of discrimination against minority viewpoints, depending on how one defines a work's "ideal reader." For example, if preference is given to the aesthetic understanding of members of the putative "art world," then the viewpoints of people who are not members of that world are necessarily excluded. This excluded group would contain

110 See id.

111 This aesthetic position goes back at least as far as the Romans, who had an expression: de gustibus non disputandum est ("there is no disputing of tastes"). See Jesse Prinz, Really Bad Taste, in KNOWING ART: ESSAYS IN AESTHETICS AND EPISTEMOLOGY 95 (Matthew Kieran \& Dominic Mciver Lopes eds., 2007).

112 See Jonathan Culler, Structuralist Poetics: StructuralisM, Linguistics and the STUDY OF LITERATURE 123-24 (1975); Yen, supra note 22, at 265-66 ("The trick to a correct interpretation ... becomes the selection of a particular reader whose perspective is elevated above others."); Tolhurst, supra note 35, at 12 . Given the rough equivalence between the hypothetical reader offered by Reader-Response theory and the well-established legal fiction of the "reasonable person," it would seem that this theory offers the best interpretative fit for courts. See, e.g., United States v. Carroll Towing Co., 159 F.2d 169, 173 (2d Cir. 1947) (providing a test for determining the decisionmaking process of a hypothetical reasonable person); see also infra Part III.

113 See CULLER, supra note 112, at 123-24. However, the risk of Reader-Response theory devolving into Formalism is not as great as the risk that it might turn into Intentionalism. See Yen, supra note 22 , at $265-66$.

114 See, e.g., Tolhurst, supra note 35, at 11 (arguing that the correct meaning of a text is best understood as the "intention which a member of the intended audience would be most justified in attributing to the author based on the knowledge and attitudes which he possess by virtue of being a member of the intended audience").

115 See Yen, supra note 22, at 266.

116 See id. 
many artists and art practices that have not garnered significant commercial or scholarly recognition, such as "outsider artists." 117

This brief introduction provides a general framework for thinking about the fault lines in artistic interpretation and the challenges presented to courts in thinking through aesthetic issues in a systematically consistent way. ${ }^{118}$ Though it may be true that "[n]o one can say with assurance what a work of art is," 119 this bare fact should not dissuade courts from engaging with aesthetic thought anymore than they should avoid similarly indeterminate areas of knowledge such as economics, psychology, and religion. ${ }^{120}$ Moreover, as we will see in the next Part, copyright law demands that courts make aesthetic determinations, and rendering such judgments without acknowledgment of aesthetic theory has led to doctrinal confusion. Thus, because courts cannot avoid making artistic judgments, ${ }^{121}$ they need to be cognizant of the theoretical underpinnings of these judgments, elusive though they may be.

\section{SPECIFIC INSTANCES OF AESTHETIC JUDGMENTS IN COPYRIGHT CASE LAW}

In this Part, we provide an overview of instances in which copyright doctrine requires artistic evaluations. We also identify instances where courts use arguments that closely mirror aesthetic theories. Formalism, Intentionalism, and Reader-Response theories are all utilized, albeit implicitly, in judicial decisions on a wide range of issues in copyright law, including eligibility, originality, authorship, infringement, and fair use. ${ }^{122}$

\section{A. The Province of Copyright Law: Works by "Authors"}

The Copyright Act provides that a fundamental requirement for copyright protection is that a work must be an "original work[] of

117 See generally COLIN RHODES, OUTSIDER ART: SPONTANEOUS ALTERNATIVES (2000) (discussing works created by artists on the margins of the art world and society, such as psychiatric patients, criminals, recluses, etc.); PARALLEL VISIONS: MODERN ARTISTS AND OUTSIDER ART (Maurice Tuchman \& Carol Eliel eds., 1992) (discussing the same).

${ }^{118}$ Our discussion of aesthetic theory is not comprehensive, either in the breadth of the models presented or their conceptual depth. For a more in-depth treatment of these philosophies, see generally THEODOR W. ADORNO, AESTHETIC THEORY (1997); DANTO, supra note 46; and TERRY EAGLETON, THE IDEOLOGY OF THE AESTHETIC (1990).

119 ROSENBERG, supra note 85 , at 12 .

120 See supra notes $1-4$.

121 See infra Part III.

122 See Farley, supra note 9, at 845-49 ("[C]ourts are not self-conscious or explicit about the theories of art they are employing. ... Their invocation of these theories is intuitive, not deliberate."). 
authorship,"123 but the Act neither defines "authorship" nor "originality."124 Courts have struggled with the meaning of these terms, in no small part because defining them requires an implicit inquiry into the creative process. For instance, on the one hand, the standard of "originality" is relatively low. It does not require novelty, ingenuity, or any particular benchmark of artistic merit. On the other hand, however, an "original work of authorship" implies some "authorial" presence. A work must be "independently created by authors" and involve some minimal "creative spark." 125 In the words of Benjamin Kaplan, "[T]o make the copyright turnstile revolve, the author should have to deposit more than a penny in the box ...." ${ }^{\prime 26}$ Indeed, as the Supreme Court clarified in Feist Publications, Inc. v. Rural Telephone Service Co., the mere investment of time and industrious labor (i.e., "sweat of the brow") does not justify copyright protection. ${ }^{127}$ The historical evolution of this originality standard illustrates how issues of aesthetic determination loom large in disputes where the protectability of a work is at issue. ${ }^{128}$

For instance, in expanding copyright protection to photographs in 1884, the Supreme Court distinguished photographs that are the "original

12317 U.S.C. $\$ 102($ a) (2012). Prior to the 1976 Copyright Act's explicit reference, courts have traditionally read an originality requirement implicit in the copyright statute. See JULIE E. COHEN ET AL., COPYRIGHT IN A GLOBAL INFORMATION ECONOMY 57-58 (2010). Countries around the world employ various standards of copyright eligibility. Italy, France, and several other European countries require that a work is the "personal expression of [the] author." Herman Cohen Jehoram, The EC Copyright Directives, Economic and Authors' Rights, 25 INT'L REV. IND. ProP. \& COPYRIGHT L. 821, 828-29 (1994). Japan has a stringent originality requirement that "thoughts or sentiments are expressed in a creative way" so to "fall within the literary, scientific, artistic or musical domain." Michael J. Bastian, Protection of "Noncreative" Databases: Harmonization of United States, Foreign and International Law, 22 B.C. INT'L \& COMP. L. REV. 425, 433 (1999).

124 See $\$ 101$.

125 In Feist Publications, Inc. v. Rural Telephone Service Co., the Supreme Court emphasized that originality implies that a work is "independently created by authors (as opposed to copied from other works)." 499 U.S. 340, 345 (1991). Still, the Supreme Court maintained the long-standing judicial standard that "some creative spark" is required for a work to be eligible for copyright protection: "There remains a narrow category of works in which the creative spark is utterly lacking or so trivial as to be virtually nonexistent. Such works are incapable of sustaining a valid copyright." $I d$. at 345,359 (citation omitted) (holding that telephone white pages directory lacked the minimal originality to satisfy the constitutional requirement of originality).

126 Benjamin KaPLAN, AN UNHURRIEd VIEW OF COPYRIGHT (Columbia University Press 1967), reprinted in BENJAMIN KAPLAN ET AL., AN UNHURRIED VIEW OF COPYRIGHT REPUBLISHED (AND WITH CONTRIBUTIONS FROM FRIENDS) 46 (Iris C. Geik et al. eds., 2005).

127499 U.S. at 349 ("The primary objective of copyright is not to reward the labor of authors, but 'to [p]romote the Progress of Science and useful Arts."' (alteration in original) (quoting U.S. CoNST. art. I, $\S 8, \mathrm{cl} .8$ ) (citing Twentieth Century Music Corp. v. Aiken, 422 U.S. 151, 156 (1975))); see also Jane C. Ginsburg, Creation and Commercial Value: Copyright Protection of Works of Information, 90 COLUM. L. REV. 1865 (1990).

${ }^{128}$ For a description of the history of originality in copyright law, see Dale P. Olson, Thin Copyrights, 95 W. VA. L. REV. 147 (1992) (focusing on copyright in compilations and the rejection of "sweat of the brow" and "industrious compilation" to the Feist standard of originality). 
mental conception" and "intellectual invention" of the photographer from unprotected photographs that consist of a "mere mechanical reproduction of the physical features or outlines of some object."129 Although even "crude, humble or obvious" contributions to the arts are eligible for protection, "some creative spark" is nevertheless required. ${ }^{130}$ In BurrowGiles Lithographic Co. v. Sarony, the Supreme Court held that a photograph of Oscar Wilde was protected, noting its qualities as a

useful, new, harmonious, characteristic, and graceful picture, and that plaintiff made the same ... entirely from his own original mental conception, to which he gave visible form by posing the said Oscar Wilde in front of the camera, selecting and arranging the costume, draperies, and other various accessories in said photograph, arranging the subject so as to present graceful outlines, arranging and disposing the light and shade, suggesting and evoking the desired expression, and from such disposition, arrangement, or representation, made entirely by plaintiff, he produced the picture in suit. ${ }^{131}$

Two different aesthetic theories animated the Court's decision. First, in order to assess whether the work was sufficiently creative, the Court turned to the work's physical form when it described the photograph as "useful, new, harmonious, characteristic and graceful." 132 Second, the reference to the author's creative "selection and arrangement" of the photograph "implies that originality depends on the operation of a putative author's mind, and not the features of the work itself." 133 The Burrow-Giles precedent set courts on the path of both Formalistic and Intentionalist interpretations of creative works.

For instance, in Alfred Bell \& Co. v. Catalda Fine Arts, the Second Circuit faced the difficult question of whether mezzotint reproductions of classic works could receive copyright protection. ${ }^{134}$ The goal of the author of such prints may have been to create an exact replica of the original, but the process of mezzotint engraving necessarily created variations between the original and the reproduced versions. The court ignored the intent of the

129 Burrow-Giles Lithographic Co. v. Sarony, 111 U.S. 53, 59-60 (1884) (finding creative decisions in the selection and arrangement of clothing, lighting, and the subject made a photograph of Oscar Wilde an original work); see also Ets-Hokin v. Skyy Spirits, Inc., 225 F.3d 1068, 1073 (9th Cir. 2000) ("It is well recognized that photography is a form of artistic expression, requiring numerous artistic judgments."); Rogers v. Koons, 960 F.2d 301, 307 (2d Cir. 1992) ("Elements of originality in a photograph may include posing the subjects, lighting, angle, selection of film and camera, evoking the desired expression, and almost any other variant involved."); E. Am. Trio Prods., Inc. v. Tang Elec. Corp., 97 F. Supp. 2d 395, 417 (S.D.N.Y. 2000) ("There is a very broad scope for copyright in photographs, encompassing almost any photograph that reflects more than 'slavish copying."').

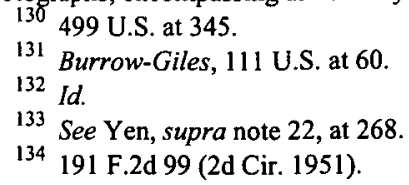


alleged author in favor of an analysis of the physical form of the plaintiff's work-a classic example of a court deploying aesthetic Formalism. The court held that any "distinguishable" variation between the original and subsequent work is sufficient to support a copyright. ${ }^{135}$ Discerning a "distinguishable" variation in a work requires aesthetic interpretation squarely at odds with the doctrine of avoidance..$^{136}$

It is also important to note that decisions about creativity and originality are not presented to courts as simple, binary yes-no questions. Copyright disputes often compel courts to assess the degree of creativity in a work. Even if a work is considered original enough to receive protection, the amount of creativity involved affects the scope of protection afforded the work. Copyright law provides less protection (i.e., "thin copyright") to works that involve only modest levels of originality, as opposed to "thick copyright" for more creative works. ${ }^{137}$ In general, if a work displays only minimal creativity, then only slavish copying or virtually identical reproductions will infringe on the copyright of the work. ${ }^{138}$ As a result, courts must distinguish between works that require less creativity to produce and those on a higher creative plane. ${ }^{139}$ In other words, it is not sufficient for courts to merely identify an artistic contribution; judges must

${ }^{135}$ Id. at 105 ("A copyist's bad eyesight or defective musculature, or a shock caused by a clap of thunder, may yield sufficiently distinguishable variations.").

${ }^{136}$ Courts would adapt a hybrid version of Formalist and Intentionalist analyses. For a discussion of originality in reproductions, see infra, Part III.B.

137 See Feist Publ'ns, Inc. v. Rural Tel. Servs. Co., 499 U.S. 340, 349 (1991) ("[T] factual compilation [involving a minimal degree of creativity] is thin.").

${ }^{138}$ As Judge Learned Hand observed: "[T]he less developed the characters, the less they can be copyrighted; that is the penalty an author must bear for marking them too indistinctly." Nichols v. Universal Pictures Corp., 45 F.2d 119, 121 (2d Cir. 1930); see, e.g., Apple Computer v. Microsoft Corp., 35 F.3d 1435, 1447 (9th Cir. 1994) (noting that because the similarities in two software programs came from basic ideas and their obvious expressions, the works as a whole would have to be virtually identical for infringement to have occurred); Johnson Controls, Inc. v. Phoenix Control Systems, Inc., 886 F.2d 1173, 1175 (9th Cir. 1989) (finding thin copyright when there are only limited ways to express an idea); Concrete Mach. Co. v. Classic Lawn Ornaments, Inc., 843 F.2d 600, 606-07 (1st Cir. 1988) (noting that "mere identity of ideas" in two works is insufficient to give rise to infringement); see also David E. Shipley, Thin but Not Anorexic: Copyright Protection for Compilations and Other Fact Works, 15 J. INTELL. PROP. 91 (2007) (discussing Feist and the limits of copyright as applied to fact intensive works).

139 Based on the writings by Ginsburg and Gorman, it has been suggested that copyright infringement cases involve the distinction between "high-authorship" works, displaying "the individual personality of the author, through expression of emotion, imagination, and artistic creativity," and "lowauthorship" works, those with "rich . . . ideas, facts, and/or useful information." Ronald B. Standler, Copyright Protection for Nonfiction or Compilations of Facts in the USA 5 (Apr. 20, 2013) (unpublished manuscript) (available at http://www.rbs2.com/cfact.pdf [http://perma.cc/LMC9-XZMZ]) (referencing Ginsburg, supra note 127, at 1873-93, and Robert Gorman, Copyright Protection for the Collection and Representation of Facts, 76 HARV. L. REV. 1569, 1570 (1963)). Within these groups, the degree of creativity also likely affects the scope of protection against infringement. 
also discern and distinguish between various levels of creativity, thereby implicating aesthetic theory. ${ }^{140}$

\section{B. A "Spark of Originality" in Derivative Works}

When a creator has reproduced a work that is in the public domain, an aesthetic evaluation of the "creative" differences between the original work and the reproduction is required. ${ }^{141}$ Courts must distinguish between trivial or mechanical variations and variations that have a "spark of originality"142 or that are "recognizably" that of the author. ${ }^{143}$

For example, in Alva Studios, Inc. v. Winninger, the court granted copyright protection to a replica of the public domain Hand of God sculpture by Rodin. ${ }^{144}$ In doing so, the court praised the "precise, artistic" qualities of the reproduction, and commended the "skill and originality" involved, paying close attention to formal aspects of the derivative work:

It is undisputed that the original sculpture owned by the Carnegie Institute is 37 inches and that plaintiff's copyrighted work is $18 \frac{1}{2}$ inches.

The originality and distinction between the plaintiff's work and the original also lies in the treatment of the rear side of the base. The rear side of the original base is open; that of the plaintiff's work is closed. We find that this difference when coupled with the skilled scaled sculpture is itself creative. ${ }^{145}$

Similarly, in denying copyright protection to plastic novelty bank in the shape of Uncle Sam, a character in the public domain, the Second Circuit in L. Batlin \& Son, Inc. v. Snyder stated that reproductions of works in the public domain must demonstrate a degree of "true artistic skill" that extends beyond physical skills or training, such that the artist creates a "substantial variation" of the original work. ${ }^{146}$ In analyzing the various differences between the original public domain work and the work seeking

${ }^{140}$ See infra Part Il.B.

141 Alfred Bell \& Co. v. Catalda Fine Arts, Inc., 191 F.2d 99, 102 (2d Cir. 1951) (setting a "distinguishable variation" standard to assess whether the author of the derivative work has made an independent contribution).

${ }^{142}$ Bridgeman Art Library, Ltd. V. Corel Corp., 36 F. Supp. 2d 191, 197 (S.D.N.Y. 1999) (stating that copyright is not available for "slavish" photographic copies of classic paintings).

143 Alfred Bell, 191 F.2d at 103 (stating that mezzotint engravings of paintings sufficiently depart from underlying works to qualify for copyright protection).

144177 F. Supp. 265 (S.D.N.Y. 1959).

145 Id. at 267.

146536 F.2d 486, 491 (2d Cir. 1976) (en banc). With regard to variations on copyrighted works, see Durham Indus. v. Tomy Corp., 630 F.2d 905, 909 (2d Cir. 1980) (introducing a two-part test to assess copyright claim on a derivative work by a third party who does not hold the copyright on the underlying original work); Entm't Research Grp., Inc. v. Genesis Creative Grp., Inc., 122 F.3d 1211, 1220 (9th Cir. 1997) (stating that to support a copyright claim, variations between original and derivate work must be more than trivial). 
protection, the court reviewed in detail the formal differences between both works:

Similarities include, more importantly, the appearance and number of stripes on the trousers, buttons on the coat, and stars on the vest and hat, the attire and pose of Uncle Sam, the decor on his base and bag, the overall color scheme, the method of carpetbag opening, to name but a few. ${ }^{147}$

Yet, unlike in Alva, the court also considered art historical conditions surrounding the original work. The Batlin court noted that the Uncle Sam Bank did not belong in a "category of substantial originality," and was not the "creativity in the underlying work of art of the same order of magnitude as in the case of the "Hand of God." 148 Rodin's sculpture is also largely inaccessible to the general public so a significant public benefit accrues from its precise, artistic reproduction. ${ }^{149}$ "No such benefit [was] imagined to accrue ... from the 'knock-off' reproduction of the cast iron Uncle Sam bank."150

To some degree, issues of distinguishable variation emerge in all areas of the creative arts. For instance, in the context of realistic photographs of existing works, photos will receive copyright protection as derivative works only if the photographer has "recast, transformed, or adapted"151 the original work in an original manner that cannot be deemed trivial. ${ }^{152}$ Here as well, the degree of creativity in the original work being photographed may factor into how much, if any, copyright protection is granted to a derivative work. ${ }^{153}$

\section{Useful or Expressive Works}

Whenever a creative work also has utilitarian features, copyright law must assess the overall character of the work to determine whether it is

147 Batlin, 536 F.2d at 489.

148 Id. at 492.

149 Id.; cf. Alva Studios, 177 F. Supp, at 267 (explaining the artistic merit involved in the creation of a scaled down replica of Rodin's Hand of God).

150 Batlin, 536 F.2d at 492.

151 17 U.S.C. $\$ 101(2012)$.

152 Schrock v. Learning Curve Int'l, Inc., 586 F.3d 513, 522 (7th Cir. 2009) (granting copyright on pictures of toys for promotional materials because the photographs possessed sufficient incremental original expression); SHL Imaging, Inc. v. Artisan House, Inc., 117 F. Supp. 2d 301, 311 (S.D.N.Y. 2000) (granting thin copyright protection on the "totality of the precise lighting selection, angle of the camera, lens and filter selection" for photographs of mirrored picture frames for promotional materials).

${ }^{153}$ Ets-Hokin v. Skyy Spirits, Inc., 225 F.3d 1068, 1080 (9th Cir. 2000) (in determining issue of copyrightability and infringement of photographs of bottle, the court analyzed the creativity of the original work that was being photographed: "The Skyy vodka bottle, although attractive, has no special design or other features that could exist independently as a work of art. It is essentially a functional bottle without a distinctive shape."). 
eligible for copyright protection. ${ }^{154}$ If a work primarily serves utilitarian purposes, its protection is the province of patent law. ${ }^{155}$ In the overall scheme of intellectual property law, "technical" innovations belong in the patent sphere while "artistic" contributions belong in the copyright sphere. ${ }^{156}$

But, the practical implementation of this fundamental premise has proven extremely difficult. To exclude useful articles from protection, copyright law must draw a line between articles that serve a useful purpose and those that are merely aesthetically pleasing. Here, once again, courts are forced to engage in aesthetic evaluation.

The Copyright Act instructs courts to grant copyright protection only if a work contains aesthetic features that "can be identified separately from, and are capable of existing independently of, the utilitarian aspects."157 Additionally, when a work's useful and aesthetic features are so intertwined that they cannot be separated physically, courts must consider

\footnotetext{
154 The 1976 Copyright Act provides the following definition of pictorial, graphic, and sculptural works:

Pictorial, graphic, and sculptural works include two-dimensional and three-dimensional works of fine, graphic, and applied art, photographs, prints and art reproductions, maps, globes, charts, diagrams, models, and technical drawings, including architectural plans. Such works shall include works of artistic craftsmanship insofar as their form but not their mechanical or utilitarian aspects are concerned; the design of a useful article, as defined in this section, shall be considered a pictorial, graphic, or sculptural work only if, and only to the extent that, such design incorporates pictorial, graphic, or sculptural features that can be identified separately from, and are capable of existing independently of, the utilitarian aspects of the article.

17 U.S.C. § 101 (2012) (internal quotation marks omitted). See Robert C. Hauhart, The Eternal Wavering Line-The Continuing Saga of Mazer v. Stein, 6 HAMLINE L. REV. 95, 104 n.52 (1983).

155 Esquire, Inc. v. Ringer, 591 F.2d 796, 806 (D.C. Cir. 1978), cert. denied, 440 U.S. 908 (1979) (stating that lighting fixtures designed with unusual elliptically shaped housings were not eligible for copyright protection as works of art because there were no separately identifiable artistic elements). The court noted that the 1976 Act found ineligible for copyright "the overall design or configuration of a utilitarian object, even if it is determined by aesthetic as well as functional considerations." Id. at 804 .

156 The seminal case is Baker v. Selden, 101 U.S. 99, 102 (1879). In Baker, the Court held that a system of book-keeping is not copyright eligible subject-matter:

To give to the author of the book an exclusive property in the art described therein, when no examination of its novelty has ever been officially made, would be a surprise and a fraud upon the public. That is the province of letters-patent, not of copyright. The claim to an invention or discovery of an art or manufacture must be subjected to the examination of the Patent Office before an exclusive right therein can be obtained; and it can only be secured by a patent from the government.

Id. at 102 . On the problematic nature of granting copyright for useful articles, see, for example, Julie E. Cohen \& Mark A. Lemley, Patent Scope and Innovation in the Software Industry, 89 CALIF. L. REV. 1, 26-27 (2001) ("A variety of doctrines historically have served to channel certain sorts of innovation (technical) into the patent sphere and other sorts (artistic) into the copyright sphere."); Viva R. Moffat, Mutant Copyright and Backdoor Patents: The Problem of Overlapping Intellectual Property Protection, 19 BERKELEY TECH. L.J. 1473, 1512-13 (2004) ("Overlapping protection in these areas disrupts both the patent and copyright bargains. Each of these bargains falls apart when an alternative form of protection is available for the invention or creative work.").

$157 \S 101$.
} 
whether there is conceptual separability between the form and function of a work, with copyright extending only to the form.

To establish whether separate copyrightable features are present, courts apply opposing artistic theories of interpretation, often mixing various incompatible theories together in one decision. For instance, in Kieselstein-Cord v. Accessories by Pearl, Inc., the Second Circuit held that the useful aspects of decorative belt buckles could be sufficiently separated from their ornamental aesthetic features. ${ }^{158}$ In finding that the buckles in question "rise to the level of creative art,"159 the court referred to the intentions of the buckles' creator. ${ }^{160}$ The court also invoked ReaderResponse theory by noting that the buckles were well received in art and fashion circles, ${ }^{161}$ and by rejecting the notion that the utilitarian nature of fashion items excludes them from copyright protection. "[B]ody ornamentation has been an art form since the earliest days, as anyone who has seen the Tutankhamen or Scythian gold exhibits at the Metropolitan Museum will readily attest." 162 In other words, fashion items can be art when they are perceived as such by society.

In a different decision by the same circuit, however, the court followed a strict Formalist approach, finding that it was impossible to distinguish between the expressive and useful aspects of human torso sculptures that had been used as mannequins. ${ }^{163}$ The Carol Barnhart Inc. v. Economy Cover Corp. court reasoned that mannequin forms are not aesthetic creations because they conform to realistic proportions, e.g., "the life-size configuration of the breasts and the width of the shoulders."164 In a spirited dissent, however, Judge Newman advocated a Reader-Response approach to conceptual separability:

How, then, is "conceptual separateness" to be determined? In my view, the answer derives from the word "conceptual." For the design features to be "conceptually separate" from the utilitarian aspects of the useful article that embodies the design, the article must stimulate in the mind of the beholder a

158632 F.2d 989, 993-94 (2d Cir. 1980).

159 Id. at 994.

${ }^{160}$ Id. at 991 ("Explaining why he named the earlier buckle design 'Winchester,' the designer said that he saw 'in [his] mind's eye a correlation between the art nouveau period and the butt of an antique Winchester rifle' and then 'pulled these elements together graphically."' (alteration in original)).

${ }_{161}$ Id. ("Sales of both buckles were made primarily in high fashion stores and jewelry stores, bringing recognition to appellant as a 'designer.' This recognition included a 1979 Coty American Fashion Critics' Award for his work in jewelry design as well as election in 1978 to the Council of Fashion Designers of America. Both the Winchester and the Vaquero buckles, donated by appellant after this lawsuit was commenced, have been accepted by the Metropolitan Museum of Art for its permanent collection.").

${ }_{162}$ Id. at 994 .

${ }^{163}$ Carol Barnhart Inc. v. Econ. Cover Corp., 773 F.2d 411, 419 (2d Cir. 1985) (analysis based on Formalism).

${ }_{164} I d$. 
concept that is separate from the concept evoked by its utilitarian function. The test turns on what may reasonably be understood to be occurring in the mind of the beholder or, as some might say, in the "mind's eye" of the beholder. This formulation requires consideration of who the beholder is and when a concept may be considered "separate."

I think the relevant beholder must be that most useful legal personage- the ordinary, reasonable observer. ${ }^{165}$

Two years later, in Brandir International, Inc. v. Cascade Pacific Lumber Co., an entirely different theory of artistic evaluation emerged in the same circuit: the merger test. ${ }^{166}$ In denying copyright protection on the Ribbon Bike Rack, ${ }^{167}$ Judge Oakes mixed together both Formalism and Intentionalism, while explicitly rejecting a Reader-Response interpretation. ${ }^{168}$ The court began with a strict formal analysis:

In creating the RIBBON Rack, the designer has clearly adapted the original aesthetic elements to accommodate and further a utilitarian purpose. These altered design features of the RIBBON Rack, including the spacesaving, open design achieved by widening the upper loops to permit parking under as well as over the rack's curves, the straightened vertical elements that allow in- and above-ground installation of the rack, the ability to fit all types of bicycles and mopeds, and the heavy-gauged tubular construction of rustproof galvanized steel, are all features that combine to make for a safe, secure, and maintenance-free system of parking bicycles and mopeds. ... Moreover, the rack is manufactured from $23 / 8$-inch standard steam pipe that is bent into form, the six-inch radius of the bends evidently resulting from bending the pipe according to a standard formula that yields bends having a radius equal to three times the nominal internal diameter of the pipe. ${ }^{169}$

But then the court looked to the artist's intentions, noting that "he did not give any thought to the utilitarian application of any of his sculptures."170 Ultimately, the court denied copyright protection to the Ribbon Rack because the author had adapted the original aesthetic elements to accommodate the sculpture's purpose as a bicycle rack. As a result of these adaptations, the sculpture no longer "reflect[ed] the unconstrained

${ }^{165}$ Id. at 422 (Newman, J., dissenting).

166834 F.2d 1142, 1145 (2d Cir. 1987). "[I]f design elements reflect a merger of aesthetic and functional considerations, the artistic aspects of a work cannot be said to be conceptually separable from the utilitarian elements." Id. (referencing Robert C. Denicola, Applied Art and Industrial Design: A Suggested Approach to Copyright in Useful Articles, 67 MINN. L. REV. 707, 741 (1983)).

167 The Ribbon Bike Rack is a unique bicycle rack that consists of "graceful curves of tubular steel." RIBBON BIKE RACK, http://www.ribbonrack.com [http://perma.cc/535R-PSTN].

${ }_{168}$ The court rejected the Reader-Response theory advocated by Judge Newman: "[I]t is not enough that, to paraphrase Judge Newman, the rack may stimulate in the mind of the reasonable observer a concept separate from the bicycle rack concept." Brandir, 834 F.2d at 1147.

${ }_{170} I d$.
$I d$. at 1146. 
perspective of the artist," 171 and it did not matter that the (altered) final product was widely celebrated as a highly functional, creative design. ${ }^{172}$

As these opposing opinions of the Second Circuit illustrate, ${ }^{173}$ courts face a difficult challenge determining conceptual separability. But by randomly switching between major aesthetic theories that are theoretically incompatible, courts make this challenge even more difficult for themselves, and as a consequence, the case law fails to provide artists with guidance as to the scope of protection available to such works.

\section{Creative Transformations as Fair Use}

Artistic determinations are inescapable when courts decide disputes involving alleged fair uses of copyrighted material. ${ }^{174}$ Aesthetic sensitivity is especially important to the first factor of the fair use test, which requires courts to assess the "purpose and character" of a purported fair use. ${ }^{175}$ The relevant inquiry is whether the allegedly infringing work merely "'supersede[s] the objects' of the original creation, or instead adds something new, with a further purpose or different character, altering the

171 Id. at 1145. For an application of the Second Circuit's test by the Seventh Circuit, see Pivot Point International, Inc. v. Charlene Products, Inc., 372 F.3d 913, 931-32 (7th Cir. 2004), which determined that the design of a mannequin head meant to depict a fashion model satisfied conceptual separability because the designer's judgment was unaffected by functional concerns. See also Mannequin Head Depicting "Hungry Look" High-Fashion Runway Model Is Protected by Copyright, After All, Federal Appellate Court Rules, ENT. L. REP., Nov. 2004, at 18, available at http://elr.carolon.net/BV/v26n06.pdf [http://perma.cc/6J79-U6LD] (discussing the Seventh Circuit's decision in Pivot Point).

${ }^{172}$ See Brandir, 834 F.2d at 1146 ("The RIBBON Rack has been featured in Popular Science, Art and Architecture, and Design 384 magazines, and it won an Industrial Designers Society of America design award in the spring of 1980. In the spring of 1984 the RIBBON Rack was selected from 200 designs to be included among 77 of the designs exhibited at the Katonah Gallery in an exhibition entitled 'The Product of Design: An Exploration of the Industrial Design Process,' an exhibition that was written up in the New York Times.").

${ }^{173}$ See 1 Paul Goldstein, Copyright: Principles, Law and Practice $\$ 2.5 .3$, at 99 (1989) ("Of the many fine lines that run through the Copyright Act, none is more troublesome than the line between protectable pictorial, graphic and sculptural works and unprotectable utilitarian elements of industrial design."). For an overview, see John B. Fowles, The Utility of a Bright Line Rule in Copyright Law: Freeing Judges from Aesthetic Controversy and Conceptual Separability in Leicester v. Warner Bros., 12 UCLA ENT. L. REV. 301 (2005).

${ }^{174}$ Following Article 107 of the Copyright Act, "fair" uses of copyrighted materials are not an infringement of copyright. See 17 U.S.C. $\$ 107$ (2012). Courts must determine on a case-by-case basis whether any particular use of the copyrighted work is fair. Id.

175 The judicially developed fair use test commands courts to consider at least four different aspects of any fair use dispute:

(1) the purpose and character of the use;... (2) the nature of the copyrighted work; (3) the amount and substantiality of the portion used in relation to the copyrighted work as a whole; and

(4) the effect of the use upon the potential market for or value of the copyrighted work.

Id. In the words of Judge Leval, the first factor is "the soul of fair use." Pierre N. Leval, Commentary, Toward a Fair Use Standard, 103 HARV. L. REV. 1105, 1116 (1990). 
first with new expression, meaning, or message."176 A fair use finding is more likely if "the secondary use adds value to the original-if copyrightable expression in the original work is used as raw material, transformed in the creation of new information, new aesthetics, new insights and understandings."177

Sometimes the determination of the "character" of an allegedly infringing use is straightforward-e.g., when a work is copied verbatim. ${ }^{178}$ Many other disputes, however, involve situations in which a defendant has integrated copyrighted material into a new creative work without permission. In these instances, courts must dissect the "relationship" between the original copyrighted material and the allegedly infringing work to assess whether the use is "of the transformative type that advances knowledge and the progress of the arts or whether it merely repackages, free riding on another's creations." 179

When drawing a line between new works that transform a preexisting work and works that are more derivative in nature, courts must rely on some comparative standard in order to evaluate the relationship between the original and the infringing works. Here, again, courts knowingly or inadvertently rely on aesthetic theories of interpretation. At times, courts seek to decipher the author's intentions. In Blanch v. Koons, for instance, a fair use finding rested on the observation that:

Koons [was], by his own undisputed description, using Blanch's image as fodder for his commentary on the social and aesthetic consequences of mass media. His stated objective [was] thus not to repackage Blanch's [artwork], but to employ it "in the creation of new information, new aesthetics, new insights and understandings." 180

${ }^{176}$ Campbell v. Acuff-Rose Music, Inc., 510 U.S. 569, 579 (1994) (alteration in original) (citations omitted); id. ("[T]ransformative works.... lie at the heart of the fair use doctrine's guarantee of breathing space ...."); see also Folsom v. Marsh, 9 F. Cas. 342, 348 (C.C.D. Mass. 1841) (No. 4901).

177 Castle Rock Entm't v. Carol Publ'g Grp., 150 F.3d 132, 142 (2d Cir. 1998) (quoting Leval, supra note 175, at 1111) (internal quotation marks omitted).

${ }^{178}$ Even wholesale copying may qualify for fair use if the copied material is, for instance, not very extensive or created for educational purposes. For examples of fair use determinations in this context, see SOFA Entm't, Inc. v. Dodger Prods., Inc., 709 F.3d 1273, 1280 (9th Cir. 2013) (finding fair use where a seven-second clip from The Ed Sullivan Show was used in a staged musical history); Religious Tech. Ctr. v. Lerma, 908 F. Supp. 1362, 1367 (E.D. Va. 1995) (finding fair use where the Washington Post used three brief quotations from Church of Scientology texts). Short excerpts and news commentary are not always granted fair use immunity, however. See, e.g., Harper \& Row, Publishers, Inc. v. Nation Enters., 471 U.S. 539, 562-63, 569 (1985) (holding that public interest in learning of that political figure's account of an historic event did not render fair use of an unpublished book); Ringgold v. Black Entm't Television, Inc., 126 F.3d 70, 77-81 (2d Cir. 1997) (rejecting fair use defense when a copy of a poster of a quilt appeared in a sitcom for twenty-seven seconds).

179 Leval, supra note 175 , at 1116.

180 Blanch v. Koons, 467 F.3d 244, 253 (2d Cir. 2006) (citation omitted); see also id. at 255 ("The question is whether Koons had a genuine creative rationale for borrowing Blanch's image ....”). 
At other times, courts resort to a more Formalistic mode of analysis in order to appraise the purpose and character of the defendant's work. For instance, toy-maker Mattel sued the artist Tom Forsythe over a series of seventy-eight photographs entitled Food Chain Barbie, depicting Barbie in various absurd and often sexualized positions. The court analyzed Food Chain Barbie's configuration in great detail, focusing on the lighting, background, props, and camera angles of the photographs. ${ }^{181}$

Occasionally, courts combine the concepts of Intentionalism and Formalism. For example, the Eleventh Circuit applied formal analysis to the configuration of a parody of Gone with the Wind to assess the credibility of the authors' stated objectives in the litigation-to destroy the "perspective, judgments, and mythology of [Gone with the Wind]," which is derisive of black people. ${ }^{182}$ The court's formal analysis is illustrated by the following passage in the decision:

Where Randall refers directly to Mitchell's plot and characters, she does so in service of her general attack on [Gone with the Wind]. In [Gone with the

181 Mattel, Inc. v. Walking Mountain Prods., 353 F.3d 792, 802-03 (9th Cir. 2003) ("Forsythe turns this image on its head, so to speak, by displaying carefully positioned, nude, and sometimes frazzled looking Barbies in often ridiculous and apparently dangerous situations. His lighting, background, props, and camera angles all serve to create a context for Mattel's copyrighted work that transform Barbie's meaning. Forsythe presents the viewer with a different set of associations and a different context for this plastic figure. In some of Forsythe's photos, Barbie is about to be destroyed or harmed by domestic life in the form of kitchen appliances, yet continues displaying her well known smile, disturbingly oblivious to her predicament. As portrayed in some of Forsythe's photographs, the appliances are substantial and overwhelming, while Barbie looks defenseless."). For other prominent examples of Formalism in fair use parody disputes, see Dr. Seuss Enterprises, L.P. v. Penguin Books USA, Inc., 109 F.3d 1394, 1401 (9th Cir. 1997). There, a holder of copyrights and trademarks for children's books brought action against a publisher that intended to publish a parody of the O.J. Simpson murder trial written in the style of the books' author:

While Simpson is depicted 13 times in the Cat's distinctively scrunched and somewhat shabby red and white stove-pipe hat, the substance and content of The Cat in the Hat is not conjured up by the focus on the Brown-Goldman murders or the O.J. Simpson trial. Because there is no effort to create a transformative work with "new expression, meaning, or message," the infringing work's commercial use further cuts against the fair use defense.

Id. (referencing Campbell, 510 U.S. at 579)); see also Abilene Music, Inc. v. Sony Music Entm't, Inc., 320 F. Supp. 2d 84, 90-92 (S.D.N.Y. 2003) (finding that rapper Ghostface Killah's "sarcastic" use of "What a Wonderful World" was protected as parody: "Where the most famous recording of Wonderful World is lushly orchestrated, with strings playing the melody in a major key, evoking a feeling of peace and harmony, The Forest's version is recited a cappella, with a single male singer intoning the words off-key, in a tone that might reasonably be perceived as sarcastic. The final line of the quotation, "And I say to myself, what a wonderful world,' sounds positively ominous: While in the original, the melody ascends to the phrase 'wonderful world,' in The Forest, the entire line is intoned on a single note, negating the optimistic, happy feeling created by the original.").

182 Suntrust Bank v. Houghton Mifflin Co., 268 F.3d 1257, 1270 (11 th Cir. 2001) (establishing fair use because the book is a critical statement that "seeks to rebut and destroy the perspective, judgments, and mythology of [Gone with the Wind]," and stating that the "literary goal" of the author of the parody was "to explode the romantic, idealized portrait of the antebellum South during and after the Civil War”). 
Wind], Scarlett O'Hara often expresses disgust with and condescension towards blacks; in [the parody], Other, Scarlett's counterpart, is herself of mixed descent. In [Gone with the Wind], Ashley Wilkes is the initial object of Scarlett's affection; in [the parody], he is homosexual. In [Gone with the Wind], Rhett Butler does not consort with black female characters and is portrayed as the captain of his own destiny. In [the parody], Cynara ends her affair with Rhett's counterpart, R., to begin a relationship with a black Congressman; R. ends up a washed out former cad. In [the parody], nearly every black character is given some redeeming quality-whether depth, wit, cunning, beauty, strength, or courage-that their [Gone with the Wind] analogues lacked. ${ }^{183}$

Other judicial decisions on fair use mirror the Reader-Response theory. For instance, in the classic fair use decision involving 2 Live Crew's rap version of Roy Orbison's song "Pretty Woman," the Supreme Court ultimately determined-based on a detailed eye-of-the-beholder analysis - that 2 Live Crew's song could reasonably be perceived by the public as a comment on the original song. ${ }^{184}$

Lastly, in a recent decision involving fair use of photographs, the Second Circuit applied all three major aesthetic theories. ${ }^{185}$ Parts of the decision relied heavily on Intentionalist arguments by referring to the stated intentions of the author. ${ }^{186}$ Other parts focused on Formalist elements assessing the expressive nature of the work in reference to its "composition, presentation, scale, color palette, and medi[um]."187 But

183 Id. at $1270-71$ (footnote omitted).

184 Campbell, 510 U.S. at 582-83. The court held that the rap version of Roy Orbison's classic "Pretty Woman" could be perceived as a parody, explaining:

While we might not assign a high rank to the parodic element here, we think it fair to say that 2 Live Crew's song reasonably could be perceived as commenting on the original or criticizing it, to some degree. 2 Live Crew juxtaposes the romantic musings of a man whose fantasy comes true, with degrading taunts, a bawdy demand for sex, and a sigh of relief from patemal responsibility. The later words can be taken as a comment on the naiveté of the original of an earlier day, as a rejection of its sentiment that ignores the ugliness of street life and the debasement that it signifies.

Id. at 583 .

185 See Cariou v. Prince, 714 F.3d 694 (2d Cir. 2013).

${ }^{186} \mathrm{Id}$. at 706-07 ("Prince's deposition testimony further demonstrates his drastically different approach and aesthetic from Cariou's. Prince testified that he '[doesn't] have any really interest in what [another artist's] original intent is because ... what I do is I completely try to change it into something that's completely different.... I'm trying to make a kind of fantastic, absolutely hip, up to date, contemporary take on the music scene." (alterations in original) (quoting Prince Dep. 338:4-339:3, Oct. 6, 2009)). For a critical discussion of the case, see Anthony R. Enriquez, The Destructive Impulse of Fair Use After Cariou v. Prince, 24 DePAul J. ART TECH. \& INTELL. PROP. L. 1 (2014).

187 Cariou, 714 F.3d at 706 ("Where Cariou's serene and deliberately composed portraits and landscape photographs depict the natural beauty of Rastafarians and their surrounding environs, Prince's crude and jarring works, on the other hand, are hectic and provocative. Cariou's black-andwhite photographs were printed in a $91 / 2$ " $\times 12$ " book. Prince has created collages on canvas that incorporate color, feature distorted human and other forms and settings, and measure between ten and nearly a hundred times the size of the photographs. Prince's composition, presentation, scale, color 
ultimately, the court grounded its fair use finding in arguments that closely resembled Reader-Response (how the work "appears to the reasonable observer"). ${ }^{188}$

Again, the problem is not that courts draw from aesthetics in their opinions-this is unavoidable-but rather that they so often switch between, and blend together, incompatible theories. Is a work transformative because of the configuration of its elements, because the stated intentions of its author are clear and credible, or because of how it will be understood by its audience? Aesthetic theory teaches that each of these questions is valid in certain contexts, but if courts ask them all together it leads to a doctrinal donnybrook. As such, copyright doctrine is in desperate need of a uniform, coherent approach to deciding which is the right question to ask.

\section{A "COMMUNITY OF PRACTICE" PROPOSAL}

Surprisingly, the answer to this riddle can be drawn from its source: Bleistein. Courts have often read Justice Holmes's warning as a general proscription on aesthetic determinations. ${ }^{189}$ But Bleistein may be read more narrowly so as only to constrain aesthetic determinations in instances where judges are "trained only to the law." 190 By implication, if a judge were trained in aesthetics as well as law, then it would be permissible under Bleistein for her to apply her aesthetic knowledge in settling a dispute. ${ }^{191}$ Indeed, Holmes specifically envisioned that judges would do so, saying that even judges who lack artistic education may make aesthetic determinations within "the narrowest and most obvious limits." 192 Thus, although many courts have read Bleistein as mandating an avoidance of aesthetic questions, Holmes's language in the case supports the opposite conclusion: courts may make aesthetic judgments so long as they are sufficiently well-informed. ${ }^{193}$

palette, and media are fundamentally different and new compared to the photographs, as is the expressive nature of Prince's work.").

${ }^{188}$ Id. at 707 ("What is critical is how the work in question appears to the reasonable observer, not simply what an artist might say about a particular piece or body of work. Prince's work could be transformative even without commenting on Cariou's work or on culture, and even without Prince's stated intention to do so. Rather than confining our inquiry to Prince's explanations of his artworks, we instead examine how the artworks may 'reasonably be perceived' in order to assess their transformative nature.").

189 See Farley, supra note 9, at 817.

190 Bleistein v. Donaldson Lithographing Co., 188 U.S. 239, 251 (1903) (emphasis added).

191 See Farley, supra note 9, at 817-18.

192 Bleistein, 188 U.S. at 251.

193 See Farley, supra note 9, at 818 . Some courts have done precisely that. See, e.g., Leibovitz v. Paramount Pictures Corp., 137 F.3d 109, 111 (2d Cir. 1998) (likening a magazine photograph of actress Demi Moore naked and pregnant to Botticelli's Birth of Venus, including a complete art-historical iconography of the "Venus Pudica" pose). 
However, it is not enough for courts merely to be conversant in art and art history. To avoid the discrepancies that have resulted from applying aesthetic theory in an ad hoc manner, ${ }^{194}$ courts need to adopt a more consistent methodology for analyzing aesthetic questions. The simplest method would be for the Supreme Court to nominate a single aesthetic theory that would apply in all cases where aesthetic questions arise. ${ }^{195} \mathrm{But}$ such a bright-line approach is undesirable for at least two reasons. First, no single aesthetic theory is sufficiently broad to account for all manifestations of artistic practice. ${ }^{196}$ Therefore, to give preference to one aesthetic theory over all others would result in some forms of art being incorrectly interpreted and potentially disregarded. Additionally, establishing a rigid precedent for aesthetic judgments would reduce artistic diversity, foreclosing novel expressive forms that deviate from the theoretical standard. ${ }^{197}$ As such, a Court-sanctioned aesthetic theory could operate as a covert form of censorship that would chill aesthetic innovation, just as Justice Holmes feared. ${ }^{198}$

For instance, suppose the Court were to adopt Formalism as its exclusive aesthetic theory. ${ }^{199}$ In this scenario, courts could make aesthetic distinctions solely on the basis of the precise configuration of a work's elements that provoke "aesthetic emotion," e.g., size, shape, color, meter, timbre, rhythm, pattern, etc. ${ }^{200}$ Courts would not be permitted to consider the artist's state of mind or intention in creating the work. ${ }^{201}$ If a court were

194 See supra Part III; see also Yen, supra note 22, at 298 ("[F]amiliarity with aesthetic theory shows that courts are essentially swapping one set of aesthetic premises for others in response to the facts of particular cases.").

195 See Yen, supra note 22, at 300.

196 Compare BELL, supra note 31, at 17 (defining a formalist approach to art criticism), with Beardsley, supra note 34, at 21 ("[A]n artwork is something produced with the intention of giving it the capacity to satisfy the aesthetic interest."), and DICKIE, supra note 36, at 35-37 (arguing that an object becomes art when it is presented to members of the art world for aesthetic consideration).

197 See ROSENBERG, supra note 85, at 12 ("No one can say with assurance what a work of art isor, more important, what is not a work of art."); Danto, supra note 36, at 572-75 (discussing the aesthetic differences between Pop Art and Modern Art); cf. Rosemary J. Coombe, Objects of Property and Subjects of Politics: Intellectual Property Laws and Democratic Dialogue, 69 TEXAS L. REV. 1853, 1864-77 (1991) (arguing that intellectual property rights control the meaning of texts and suppress unapproved meanings created by certain readers and users of the texts).

198 See Bleistein v. Donaldson Lithographing Co., 188 U.S. 239, 251-52 (1903) ("[C]opyright would be denied to pictures which appealed to a public less educated than the judge. Yet if they command the interest of any public... - it would be bold to say that they have not an aesthetic and educational value - and the taste of any public is not to be treated with contempt.").

${ }^{199}$ It would do this perhaps on the basis that Formalism most closely corresponds to the interpretative approach followed by most lay observers. See Yen, supra note 22, at 262.

200 See supra notes 31-46 and accompanying text.

201 See, e.g., BELL, supra note 31 , at 19 ("In pure aesthetics we have only to consider our emotion and its object: for the purposes of aesthetics we have no right, neither is there any necessity, to pry behind the object into the state of mind of him who made it."); see also Clement Greenberg, Modernist Painting, in ART IN THEORY: 1900-1990: AN ANTHOLOGY OF CHANGING IDEAS 754-60 (Charles 
then to apply this analytical framework to Marcel Duchamp's "readymade"202 sculpture Fountain" ${ }^{203}$-wwidely considered the most influential artwork of the twentieth century ${ }^{204}$-the piece would fail to qualify as art. From a Formalist perspective, the physical qualities of Fountain are indistinguishable from a mere functional object (i.e., a urinal), so it lacks formal elements that would bring about an aesthetic experience. ${ }^{205}$ As such, if courts followed Formalism exclusively, they would be blinded to many of the aesthetic innovations that have informed twentieth- and twenty-first-century creative practice. ${ }^{206}$ This blindness, in turn, would have a considerable chilling effect on future concept-based works that deemphasize the making of aesthetically pleasing objects in favor of expressions of art as an idea. ${ }^{207}$

Suppose, instead, that the Court were to choose Intentionalism as its preferred aesthetic theory. This theoretical orientation would admit a far greater range of expressive practices than would Formalism. ${ }^{208}$ However,

Harrison \& Paul Woods eds., 1993); Wimsatt \& Beardsley, supra note 89, at 18 (arguing that an author's intended meaning is irrelevant to the analysis of a literary work).

202 A readymade is an "ordinary object elevated to the dignity of a work of art by the mere choice of an artist." See ANDRÉ BRETON \& PAUL ÉluARD, DiCTIONNAIRE ABRÉGÉ DU SURRÉAliSME (Surrealist Dictionary) (1938), available at http://www.toutfait.com/issues/issue_2/Articles/obalk.html [http://perma.cc/PRR8-5FR5].

${ }_{203}$ For this piece, Duchamp purchased a standard, mass-produced porcelain urinal, turned it on its side, signed the base using the pseudonym " $R$. Mutt," and exhibited it as the "readymade" sculpture. See CALvin TOMKINS, DuCHAMP: A BIOGRAPHY 181 (1996). A provocation against then-prevailing artistic standards that favored the visual sophistication of an artwork over the originality of its ideas, Duchamp intended Fountain and his other readymade pieces to extend the types of expressive works considered to be art. See id. at 186. Perhaps not surprisingly, Fountain has retained its ability to provoke into the present day. See, e.g., STEPHEN HICKS, EXPLAINING POSTMODERNISM: SKEPTICISM AND SOCIALISM FROM ROUSSEAU TO FOUCAULT 196 (2004) ("The artist is a not great creator-Duchamp went shopping at a plumbing store. The artwork is not a special object-it was mass-produced in a factory. The experience of art is not exciting and ennobling-at best it is puzzling and mostly leaves one with a sense of distaste. But over and above that, Duchamp did not select just any ready-made object to display. In selecting the urinal, his message was clear: Art is something you piss on.").

${ }^{204}$ See Duchamp's Urinal Tops Art Survey, BBC NEws (Dec. 1, 2004, 5:56 PM), http://news. bbc.co.uk/2/hi/entertainment/4059997.stm [http://perma.cc/B7Y3-Y9PS].

205 BELL, supra note 31, at 17-18; see also Yen, supra note 22, at 253.

206 See Jerry Saltz, Idol Thoughts: The Glory of Fountain, Marcel Duchamp's Ground-Breaking “Moneybags Piss Pot," VILlage VolCE (Feb. 21, 2006), http://www.villagevoice.com/2006-0221/art/idol-thoughts/ [http://perma.cc/52RV-7C6X].

207 Examples include Dada, Minimalism, Process Art, Performance Art, Conceptual Art, Appropriation Art, and more. See generally JONATHAN FINEBERG, ART SINCE 1940: STRATEGIES OF BEING 14-17 (3rd ed. 2000); LUCY LIPPARD, SiX YEARS: THE DEMATERIALIZATION OF THE ART OBJECT (1973); IRVING SANDLER, ART OF THE POSTMODERN ERA: From tHE LATE 1960s to THE EARLY 1990s, at 332-74 (1996) (cataloguing various art-making strategies that deemphasize the aesthetic qualities of a work of art for its intellectual content).

${ }^{208}$ Though, interestingly, under a strict Intentionalism aesthetic Duchamp's Fountain would still fail to qualify as art, on the basis that the producer of the urinal did not create it with the intent that it be displayed as an art object. See Yen, supra note 22, at 258. 
discovering the substantive meaning of a work from its author's professed intentions would create significant evidentiary problems and opportunities for outright chicanery. For instance, it would be difficult to divine with any measure of precision the exact intentions of a deceased or otherwise unavailable artist. ${ }^{209}$ Further, artists might disclaim having had artistic intentions, ${ }^{210}$ be unable to adequately express what their artistic intentions were, or strategically reimagine their intentions ex post facto to benefit their litigation posture. And, perhaps most importantly, artists' intentions might not align with the actual result of their labors, as is the case with socalled happy accidents. ${ }^{211}$ Such inferential and evidentiary challenges are not insurmountable; criminal courts regularly overcome similar obstacles to ascertain a defendant's mens rea. But given that courts are reluctant to engage in aesthetic thought generally, the adoption of an Intentionalist standard would likely be met with steep resistance.

An alternative way that courts might approach aesthetic judgments is through the lens of the "ordinary observer" test used to determine substantial similarity. ${ }^{212}$ This test does not involve analytic "dissection and expert testimony," "213 but rather depends on whether the accused work has appropriated the "total concept and feel" of the copyrighted work. ${ }^{214}$ So, rather than surveying different theories in order to map the best aesthetic topography for a particular work, courts would instead address questions of law in the same way that juries address questions of fact: by relying upon their intuitive sense of whether the "aesthetic appeal of the work is the same" to the eyes of a lay observer. ${ }^{215}$

The problems with this approach, however, are myriad. For one, use of an ordinary observer test in this way would only perpetuate the doctrinal

\footnotetext{
209 See Wimsatt \& Beardsley, supra note 89, at 18.

210 See, e.g., Harold Rosenberg, The Art World: De-Aestheticization, NEw YorkER, Jan. 24, 1970, at 62-67 (discussing Robert Morris, who signed a statement disclaiming any aesthetic content in one of his works).

211 See, e.g., Liz Massey, Embracing Creative Failure (II): Cultivating Happy Accidents, CREATIVE LIBERTY (Jan. 24, 2009), http:/creativeliberty.wordpress.com/2009/01/24/embracingcreative-failure-ii-cultivating-happy-accidents/ [http://perma.cc/5RP8BD8S].

212 Here, we speak of substantial similarity in the sense of the comparison made between works for purposes of ascertaining whether misappropriation has occurred, as opposed to the use of substantial similarity (also termed "probative" or "striking" similarity) to determine whether copying has occurred. See, e.g., Amstein v. Porter, 154 F.2d 464, 468 (2d Cir. 1946) ("If evidence of access is absent, the similarities must be so striking as to preclude the possibility that plaintiff and defendant independently arrived at the same result.").

$213 \mathrm{Id}$.

214 Roth Greeting Cards v. United Card Co., 429 F.2d 1106, 1110 (9th Cir. 1970); see also Sid \& Marty Krofft Television Prods., Inc. v. McDonald's Corp., 562 F.2d 1157, 1165-67 (9th Cir. 1977).

215 Peter Pan Fabrics, Inc. v. Martin Weiner Corp., 274 F.2d 487, 489 (2d Cir. 1960) ("[T]he ordinary observer, unless he set out to detect the disparities, would be disposed to overlook them, and regard their aesthetic appeal as the same.").
} 
inconsistencies discussed above. ${ }^{216}$ A work's "total concept and feel" is inherently subject to the quirks of individual taste and sophistication, and so decisions of law based on it are no more likely to be consistent than decisions subscribing to the doctrine of avoidance. ${ }^{217}$ Both approaches result in courts making ad hoc aesthetic determinations that provide little guidance to future litigants, or to the law generally. Likewise, for all its shortcomings, the doctrine of avoidance at least has the benefit of imposing a measure of judicial modesty that guards against the dangers of discrimination and chilling that worried Justice Holmes. ${ }^{218}$

Furthermore, the ordinary observer test is itself theoretically problematic. At its connotative root, the "total concept and feel" test ${ }^{219}$ evokes incompatible aesthetic views. For instance, the "concept" of a work cannot be established merely from its formal qualities. Rather, the trier of fact must consider external references such as an author's professed intentions, contemporaneous artistic practices, art history, social mores, cultural symbols, and more. ${ }^{220}$ Because of this, consideration of a work's concept necessitates the use of Intentionalism or Reader-Response theory (and most likely both). ${ }^{221}$ By contrast, the "feel" of a work might come directly from the work's aesthetic qualities (Formalism), ${ }^{222}$ or it could be influenced by the context in which the work is received (ReaderResponse). ${ }^{223}$ Therefore, by requiring both concept and feel, the ordinary observer test implicitly creates an aesthetic dissonance that cannot be resolved harmoniously by courts.

Luckily, these difficulties can largely be avoided by reorienting the debate from what aesthetic theory should be applied to how courts should go about applying any aesthetic theory-in other words, by shifting the question from the substantive to the procedural. This reorientation can be achieved through the judicial adoption ${ }^{224}$ of a "Community of Practice" standard for aesthetic questions. ${ }^{225}$

216 See supra Part III.

217 See supra Part II.A (discussing the doctrine of avoidance).

218 See Bleistein v. Donaldson Lithographing Co., 188 U.S. 239, 252 (1903).

219 See Roth Greeting Cards, 429 F.2d at 1110.

220 See supra note 36 and accompanying text; see also Farley, supra note 9, at 844 (discussing the "institutional approach" to defining art).

221 See, e.g., Beardsley, supra note 34, at 21 ; see also Farley, supra note 9, at 843.

222 See Yen, supra note 22, at 253.

223 For instance, a musician playing the same piece in a train station or in a concert hall will elicit a completely different "feel" from the audience. See Gene Weingarten, Pearls Before Breakfast: Can One of the Nation's Great Musicians Cut Through the Fog of a D.C. Rush Hour? Let's Find Out, WASH. POST MAG., Apr. 8, 2007 (describing experiment conducted in which violin virtuoso Joshua Bell played on a D.C. Metro train platform and was mostly ignored by commuters).

${ }^{224}$ An argument could be made here that courts are logically inconsistent in their decisionmaking in copyright cases not because of deficiencies in copyright doctrine, but because judges decide based on intuitive or normative considerations rather than reflection upon abstract principles, aesthetic or 
Our proposed Community of Practice method operates in two steps. First, the court, as briefed by the parties, would outline the general community of artistic practice from which the works in question hail. This community could be the artworld of mainstream museums, galleries, critics, etc., but it need not be so. All that is required is that the community be an accurate reflection of the aesthetic norms and traditions that informed the works.

Second, a hypothetical viewer is imagined who is part of the Community of Practice and possesses aesthetic insights that are appropriate to the interpretative questions at issue. For instance, this viewer may be the "ideal reader" of a given text, ${ }^{226}$ or may represent a consensus of aesthetic views held by persons that have studied the arts or literature. ${ }^{227}$ Or the viewer could be unfamiliar with mainstream artistic theory and practice, as would be appropriate when dealing with outsider art ${ }^{228}$ or works based in specific cultural traditions. ${ }^{229}$ In this way, the hypothetical viewer would not be limited to any specific aesthetic theory, just as a real person might alter their aesthetic criteria as they move from gallery to gallery in a museum -or from a museum out into the street. The viewer would adopt whichever theory is most sensitive to the nature of the work presented. For instance, a viewer might offer a Formalist account of a work of twelve-tone music, ${ }^{230}$ whereas they would likely apply an Intentionalist critique to a

otherwise. See, e.g., RICHARD A. POSNER, HOW JUdGES THINK (2010); $c$. JEROME FRANK, LAW AND THE MODERN MIND 108-09 (Peter Smith 1930) (arguing that judicial decisions were primarily motivated by the psychological influences on the judges). This is a fair point. However, because a thorough unpacking of this criticism is beyond the scope of this Article, we will not answer this criticism except to say that even if judges do ultimately decide based on exogenous factors, having a more rigorous analytical framework for them to contend with on the way is likely to ultimately yield greater doctrinal consistency overall.

${ }_{225}$ This proposed standard is similar in some ways to the Reader-Response "intended audience" test. See supra notes 108-16 and accompanying text for a discussion of Reader-Response theory. But see Yen, supra note 22, at 294-95 (noting that "intended audience" tests have three basic problems: (1) "authors may not have specific audiences in mind when they create a work"; (2) "the audience that forms the market... may not be the audience the author intended"; and (3) "the people for whom an author intends his work are still prone to disagree over the proper interpretation of the work").

226 "The ideal reader would ... be a person who knows everything about social conventions of interpretation and applies them correctly when reading a text." Yen, supra note 22, at 265; see also CULLER, supra note 112, at 123-24.

${ }^{227}$ See DICKIE, supra note 36 , at 68.

${ }^{228}$ See supra note 117 and accompanying text for a discussion of outsider art.

229 See, e.g., William ARNETT ET AL., THE QUilts of GeE'S BEND (2002); Glen C. Davies, STRANGER IN PARADISE: THE WORK OF REVEREND HOWARD FINSTER (2010).

${ }^{230}$ See generally GEORGE PERLE, SERIAL COMPOSITION AND ATONALITY: AN INTRODUCTION TO THE MUSIC OF SCHOENBERG, BERG, AND WEBERN (6th ed. rev. 1991); RUDOLPH RETI, TONALITY, Atonality, Pantonality: A Study of SOME TRENDS IN TWENTIETH CENTURY Music (1958); see also Greenberg, supra note 31. 
piece of Appropriation Art. ${ }^{231}$ Once the hypothetical viewer's aesthetic orientation is established, ${ }^{232}$ a court can answer questions presented based on the expected response of a viewer from the Community of Practice. As such, the Community of Practice method provides a more exact means of settling aesthetic disputes in a consistent and astute manner than the current ad hoc arrangement.

While the exact parameters of the Community of Practice standard proposed here are novel, precursors can be found throughout copyright law, most notably in Arnstein v. Porter. ${ }^{233}$ There, to determine whether wellknown songwriter Cole Porter infringed on the plaintiff's songs, the appellate court directed the lower court to consider the aesthetic views of real people ("lay listeners") in terms of "what is pleasing to the ears of lay listeners, who comprise the audience for whom such popular music is composed." 234 By the court's reckoning, not all lay opinions are equally valid. It was the aesthetic views of those who "comprise the audience" for the songs that mattered to the disposition of the case. ${ }^{235}$ Thus, the Arnstein court implicitly set out a selection procedure for determining which lay opinions a court should heed: an "intended audience" test. ${ }^{236}$ This intended audience need not be made up of actual persons who are familiar with the works at issue (say, a jury made up of Cole Porter fans), but rather may be inferred from expert testimony as to the presumed reactions of listeners for whom the songs were written. ${ }^{237}$ In other words, the intended audience is a composite built from the nature of the work itself (e.g., this song was written for that type of person) and the contexts in which the work might be presented.

Our proposed interpretative scheme also bears resemblance to the legal fiction of the "person having ordinary skill in the art" standard used in patent law. ${ }^{238}$ As with all legal fictions, the purpose of the hypothetical

231 See, e.g., Sergio Muñoz Sarmiento, Judicial Activism and the Return of Formalism in the Cariou v. Prince Decision, ClANNCo (Apr. 29, 2013), http://clancco.com/wp/2013/04/art-law-cariouprince-copyright/ [http://perma.cc/J2BG-W7H8]; see also Danto, supra note 36.

232 Either by the parties in the pleadings, or by the court sua sponte.

233 154 F.2d 464, 472-73 (2d Cir. 1946).

234 Id. (emphasis added).

235 Id.; see also Yen, supra note 22, at 293.

236 See Yen, supra note 22, at 293 ("This implies that the relevant opinions about substantial similarity are those held by the people at whom the works in question are aimed."); Tolhurst, supra note 35, at 12 (stating that the correct meaning of a text is the "intention which a member of the intended audience would be most justified in attributing to the author based on the knowledge and attitudes which he possess in virtue of being a member of the intended audience").

${ }^{237}$ See Arnstein, 154 F.2d at 472-73; see also Yen, supra note 22, at 293.

238 See 35 U.S.C. $\& 103$ (2012) ("A patent ... may not be obtained ... if the differences between the claimed invention and the prior art are such that the claimed invention as a whole would have been obvious before the effective filing date of the invention to a person having ordinary skill in the art to 
viewer is not to mimic how an actual person might respond to a given work of art, but rather to develop a baseline understanding of what a person from the Community of Practice would see as aesthetically valuable. Moreover, just as the standard for reasonableness in torts is adaptable to changing circumstances, so, too, would a Community of Practice standard be responsive to artistic innovation without sacrificing judicial consistency. Our proposed standard is objective in the sense that it is not the opinion of the court or the jury that disposes of the question, but rather what they objectively reckon a member of the Community of Practice would think under the circumstances. ${ }^{239}$

It should be noted that our proposal embraces some measure of Formalism, albeit of process rather than substance. It is important to recognize that not all formalisms are equivalent. As discussed above, the application of aesthetic Formalism provides little (if any) method for understanding works that do not rely on formal considerations as part of their aesthetic processes, such as Conceptual Art, Punk, or Cinema Verité. Procedural formalism does not have this effect. Just because a formal process is followed to determine what standards to apply to a given piece of work does not mean that the standard applied will always (or ever) be Formalism. Indeed, a court following the Community of Practice Standard could just as easily decide that Intentionalism, or Reader-Response, or some other theory not yet developed, is the best method for comparing two works of art. In other words, rigor in method can yield flexibility in thought. ${ }^{240}$

While this standard would still leave a measure of unpredictability as to the outcome of aesthetic questions, ${ }^{241}$ it would nevertheless help to rectify the confusion that arises when art is hauled into a courtroom. First, litigants would be aware of the analytical procedure used to settle aesthetic questions ex ante, which would facilitate bargaining and extrajudicial dispute resolution, as litigants would have a clearer sense of the merits of

which the claimed invention pertains."); see also KSR, Int'l Co. v. Teleflex, Inc., 550 U.S. 398, 421 (2007) ("A person of ordinary skill is also a person of ordinary creativity, not an automaton.").

239 This mirrors the objectively reasonable person standard in torts. See RESTATEMENT (SECOND) OF TORTS $\S 263$ (1965).

240 Properly conceived, our proposal provides a framework for thinking through aesthetic questions in a consistent manner while allowing for some differentiation across legal questions. For example, when faced with a fair use question, the Community of Practice would almost always consider Intentionalism as a primary aesthetic theory because intent is central to the inquiry in the first factor of the fair use test-i.e., Did the author intend their work to be transformative or not? See 17 U.S.C. $\S 107$ (2012)

241 But see supra note 194 and accompanying text for reasons why a bright-line approach to aesthetic questions would be undesirable. 
their claims. ${ }^{242}$ Second, the Community of Practice standard would help allay courts' fears of engaging in aesthetic determinations by providing a methodology for systematically sifting through art theory and historical literature and for obtaining input from experts, practitioners, and amici. ${ }^{243}$ For instance, courts could go about defining the Community of Practice in a manner roughly analogous to the way that patent examiners go about surveying the prior art to determine whether an invention is nonobvious. ${ }^{244}$

Lastly, the Community of Practice standard would serve to promote artistic innovation by establishing clearer guidelines for artists and their counsel, ${ }^{245}$ which would likely have the salutary effect of increasing artistic production, as artists would have a better idea of what is--and isn'tprotected by copyright. ${ }^{246}$ In sum, under this proposed framework, courts would approach aesthetic questions in much the same way they approach an individual's conduct in tort: under this set of (aesthetic) circumstances, what actions are to be reasonably expected, and how should a reasonably informed person respond?

\section{CONCLUSION}

It is worth remembering that courts adopted the doctrine of avoidance ${ }^{247}$ for a noble reason: "The taste of any public is not to be treated with contempt." 248 As Justice Holmes asserted, and subsequent courts have been keenly aware, ${ }^{249}$ artistic pursuits are different from other endeavors, sharing more with the dark machinery of the human spirit than the quotidian matters that are courts' normal concern. And it is precisely the

${ }^{242}$ See generally Robert Cooter et al., Bargaining in the Shadow of the Law: A Testable Model of Strategic Behavior, 11 J. LEGAL STUD. 225 (1982); Ben Depoorter, Law in the Shadow of Bargaining: The Feedback Effect of Civil Settlements, 95 CORNELL L. REV. 957 (2010).

243 See 35 U.S.C. $\$ 103$ (2012).

244 See id. ("A patent for a claimed invention may not be obtained ... if the differences between the claimed invention and the prior art are such that the claimed invention as a whole would have been obvious ... to a person having ordinary skill in the art to which the claimed invention pertains.")

${ }^{245}$ See, e.g., Liz McKenzie, Drawing Lines: Addressing Cognitive Bias in Art Appropriation Cases, 20 UCLA ENT. L. REV. 83, 85 (2013) ("[T]he open-ended nature of the copyright infringement analysis and the absence of a predictable and cohesive legal framework make copyright vulnerable to . . flawed reasoning.").

246 See Patricia Aufderheide et AL., Coll. Arts Ass'n, Copyright, Permissions, ANd Fair USE AMONG VisUal ARTISTS AND THE ACADEMIC AND MUSEUM Visual ARTS COMMUNITIES 5 (2014), available at http://www.collegeart.org/pdf/FairUseIssuesReport.pdf [http://perma.cc/Z6GUP522] (arguing that members of the visual arts community overestimate the risks of employing fair use as a result of copyright confusion and misunderstanding); Sarmiento, supra note 231 (arguing that recent copyright jurisprudence leaves artists without clear guidance as to how courts will rule on aesthetic questions).

247 See supra Part II.A.

248 Bleistein v. Donaldson Lithographing Co., 188 U.S. 239, 251-52 (1903) (holding that commercial illustrations were "art" for the purpose of copyright protection).

${ }^{249}$ See supra note 6. 
cultivation and preservation of these enigmatic and unruly forces that is the animating purpose of copyright law. ${ }^{250}$ It is thus proper for courts to exercise humility and restraint when addressing questions that could irreparably harm the creative process. The adverse effects of judicial overreach that Justice Holmes imagined ${ }^{251}$-discrimination, chilling effects, or even covert censorship-remain as virulent today as they were in 1903..$^{252}$

Yet, for all its commonsense appeal and apparent virtue, the doctrine of avoidance does more harm than good. ${ }^{253}$ Copyright law demands that courts actively engage with aesthetic issues, and no amount of evasion can change this fact. ${ }^{254}$ This feature of copyright is neither an unfortunate byproduct of misguided doctrine nor the result of the inevitable vagaries of litigation. Rather it is at the very heart of the constitutional imperative that copyright must answer: What is the best way to promote progress in the arts? ${ }^{255}$

Courts must engage with aesthetic questions because artists need guidance about the legal protections copyright affords, ${ }^{256}$ not because jurists are superior arbiters of aesthetic controversy, ${ }^{257}$ but because artists and arts communities suffer in the absence of a clear map to the contours of copyright law. ${ }^{258}$ When confusion and misunderstanding of the law abound, the result is unwarranted fear and anxiety among artists that result in a reluctance to undertake projects that venture towards uncertain legal terrain. ${ }^{259}$ In this way, the social ills that Justice Holmes sought to prevent have ironically come to pass precisely because of aesthetic avoidance and the doctrinal confusion it produces. ${ }^{260}$ For this reason, if for no other, courts must accept their responsibility to fully engage with aesthetic theory and practice-the law commands it, and artistic progress requires it. To this end, our Community of Practice proposal provides a way for courts to

${ }^{250}$ See U.S. ConST. art. I, $\S 8$, cl. 8.

251 See Bleistein, 188 U.S. at 250-52.

252 See, e.g., Campbell v. Acuff-Rose Music, Inc., 510 U.S. 569, 582-83 (1994) (citing Bleistein, 188 U.S. at 251) (noting that whether "parody is in good taste or bad does not and should not matter to fair use"); Mattel Inc. v. Walking Mountain Prods., 353 F.3d 792, 801-02 (9th Cir. 2003) (quoting Bleistein, 188 U.S. at 251) (same); Parks v. LaFace Records, 329 F.3d 437, 462-63 (6th Cir. 2003) (same); SunTrust Bank v. Houghton Mifflin Co., 268 F.3d 1257, 1268 (11th Cir. 2001) (applying Bleistein); Ets-Hokin v. Skyy Spirits, Inc., 225 F.3d 1068, 1075 (9th Cir. 2000) (same); Carol Bamhart, Inc. v. Econ. Cover Corp., 773 F.2d 411, 415 (2d Cir. 1985) (citing Bleistein, 188 U.S. 239).

253 See supra Part II.A.

254 See supra notes 22-29 and accompanying text; see also supra Part III.

255 See U.S. CONST. art. I, $\S 8, \mathrm{cl} .8$.

256 See AUFDERHEIDE ET AL., supra note 246, at 5.

257 See Bleistein, 188 U.S. at 251-52.

258 See AUFDERHEIDE ET AL., supra note 246, at 40-48.

259 See id. at 49-57.

260 See id. 
adopt a uniform approach to aesthetic judgments that will provide doctrinal lucidity, improve ex ante certainty, and promote artistic innovation. 
NORTHWESTER N UNIVERSITY LA W REVIEW 